\title{
Türkiye'de İhracatın Sektör ve Pazar Çeşitliliği Çerçevesinde Yaşadığı Yapısal Dönüşüm
}

\section{The Structural Transformation Of Turkey's Exports In Terms Of Product And Market Diversification}

\section{Hayrettin KAPLAN ${ }^{1}$, Feridun TUR ${ }^{2}$}

\begin{abstract}
In order to accomplish medium to long term targets, Turkey has to transform its structure of exports. This study aims to explore the structural transition in exports between 1995 and 2013. The calculations confirm increasing sectoral diversification and technological intensity in terms of share in total exports. On the other hand, when we focus on revealed comparative advantages, it shows that, Turkey still specializes in labor and capital intensive sectors which involves less research activity. Lastly, between 1995 and 2013 there has been a strong market diversification which implies lessening market risk via lessening market concentration. However it should be stated that, this also implies a weak potential for export growth generated by exporting same products to new markets.
\end{abstract}

Key Words: Sectoral Transformation, Structural Transformation, Product Diversification, Market Diversification, Traditional Exports

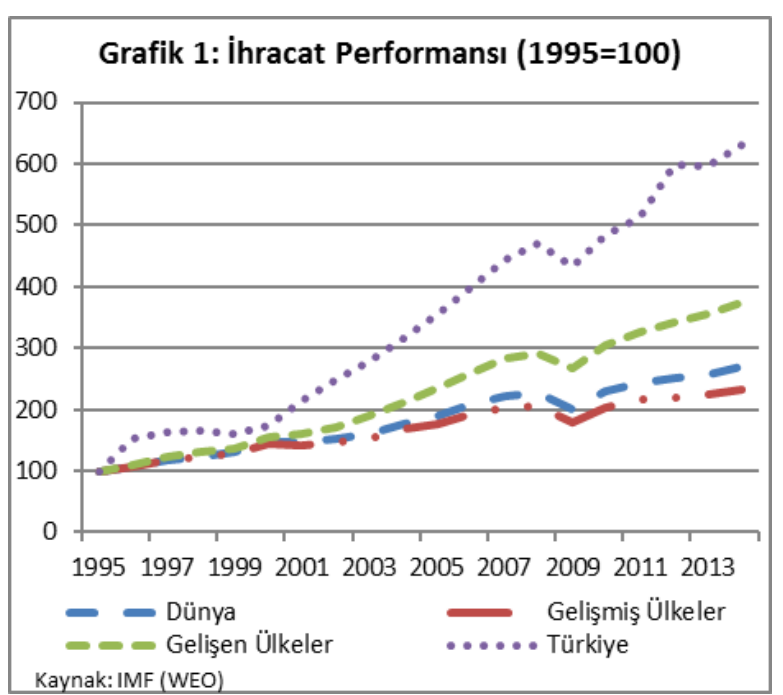

\section{GiRiş}

Türkiye'nin ihracatı 1995-2013 döneminde yıllık ortalama \%10,9 artarak 21,6 milyar dolardan 151,8 milyar dolara ulaşmıştır. Söz konusu performans, dönem boyunca dünya ortalamasının, gelişmiş ülkelerin ve gelişen ülkelerin üzerinde bir büyümeye işaret etmektedir (Grafik 1). Bu performans sonrasında Türkiye'de ihracat / GSYH 1995 yılı itibariyle \%9,6 iken, 2013 yılında \%18,5'e yükselmiştir. Türkiye'nin 19952013 döneminde gerçekleştirdiği yüksek ihracat artış performansının sürdürülebilir nitelik kazanması, yapısal bir dönüşümü gerektirmektedir. Bu çalışmada, niteliksel dönüşüm sürecinde Türkiye'nin 1995-2013 yılları arasında nasıl bir yol izlediği, ne kadar gelişim kaydettiği ve karşılaştığı tıkanıklıkların tespit edilmesi amaçlanmaktadır. 
Türkiye'nin, inceleme döneminde gerçekleşen yüksek oranlı ihracat artış performansı, dış ticarette serbestleşme sürecinin önemli bir adımı olan $A B$ ile Gümrük Birliği'nin yürürlüğe girmesinin etkilerini de barındırmaktadır. Gümrük Birliği'nin ve 2000 'li yıllarda $A B^{\prime}$ nin yaşadığı genişleme sürecinin Türkiye'nin dış ticareti üzerindeki etkileri konusunda yapılan pek çok çalışma mevcuttur (Yılmaz, 2003; Erlat ve Erlat, 2005; Utkulu ve Seymen, 2004; Vergil ve Yıldırım, 2006). Türkiye'nin Orta Doğu ülkeleri ile olan ticaretini inceleyen Erlat ve Erlat (2012a) ve BRIC (Brezilya, Rusya, Hindistan, Çin) ülkeleri ile ihracatta uzmanlaşma ve rekabet düzeylerini karşılaştıran Erkan (2012), Türkiye'nin ihracatını pazar ve/veya rakipleriyle karşılaştırma yapmak suretiyle analiz etmektedir. 1995-2010 dönemi için Türkiye'nin ihracat performansını sabit piyasa payı yöntemiyle inceleyen Aytemiz (2011), Türkiye'nin ihracat performansının altında fiyat rekabetinin yattığını, mal bileşiminin ise ihracat artışını baskılayan temel unsur olduğunu ifade etmektedir. Çalışma bunun temel nedenini Türkiye'nin ihracatında talebi görece yavaş artan emek yoğun malların ağırlıkta olması ile açıklamaktadır (Aytemiz, 2011: 197).

$\mathrm{Bu}$ çalışmada ihracatın kompozisyonundaki değişim, değişimin yönü ve niteliğinin ortaya koyulması amaçlanmaktadır. Bu çalışma çeşitli incelemelerde farklı bağlamlarda kullanılmış olan göstergelerin entegre edilmesi suretiyle sektör ve pazar kompozisyonunda yaşanan dönüşüme ilişkin daha detaylı bilgiler ortaya koymakta ve bu yönüyle yazındaki ilgili çalışmalardan farklılaşmaktadır.

Bu amaçla, sırasıyla ürün çeşitliliği, ürün kompozisyonunun niteliği, karşılaştırmalı üstünlüklerdeki gelişmeler ve ürün grupları bazında pazar yoğunlaşması temelinde ihracatın sektörel yapısındaki değişim tespit ve tahlil edilmeye çalışılacak ve çalışma, sonuçların derlenmesi ve değerlendirilmesiyle tamamlanacaktır.

Çalışmada kullanılan veriler 1995 - 2013 dönemi için SITC Rev3 kategorisindeki 255 sektör için UNCTAD'tan elde edilmiştir'. SITC Rev3 bir yandan dış ticaret araştırmalarında yoğun olarak kullanılan bir tasnif olması, diğer yandan çalışmada kullanılan teknoloji klasifikasyonuna uygun olması nedeniyle tercih edilmiştir. Çalışma 1995 yılından başlatılarak Gümrük Birliği'nin yapısal dönüşümü hızlandırıcı etkilerinin kapsanması amaçlanmıştır.

Yapısal dönüşümün sektörel boyutta incelenmesi sürecinde ürün çeşitliliği için gini katsayısı ve geleneksellik endeksi; niteliksel dönüşüm için teknolojik gruplandırma, Türkiye'nin ürünlerinin dünya piyasalarındaki göreli gücü ve bu güçteki değişim için Açıklanmış Karşılaştırmalı Üstünlükler (AKÜ) ve son olarak sektörlerin pazar yoğunluğundaki gelişimin tespit edilmesi için Herfindahl Endeksi (HE) kullanılmıştır.

\section{IHRACATTA ÜRÜN ÇEŞITLILIĞi}

İhracat ile büyüme ilişkisine odaklanan çalışmalar kapsamında, ihracat gelirlerindeki istikrara özel bir önem verilmeye başlanmıştır. Bir ülkenin ihracatta sınırlı sayıda ülkeye veya sektöre önemli ölçüde bağımlı olması durumunda; ülkenin ihracat gelirleri, ticaret ortaklarındaki ekonomik dalgalanmalardan veya ana sektörlerdeki oynaklıktan daha fazla etkilenebilmekte, bu bağlamda döviz gelirlerinde bir kırılganlık oluşabilmektedir (Erlat ve Akyüz, 2001; Değer ve Genç, 2010). Bu çerçevede, ihracatta çeşitliliğin artırılması hem pazar, hem de ürün bazında önem arz etmektedir.

Türkiye'nin $A B^{\prime} y e$ ihracatını ürün çeşitliliği bağlamında değerlendiren Ekmen-Özçelik ve Erlat (2013), gelişen ülkelerin geleneksel ihraç ürünlerinin azalan ticaret hadlerine tabi olmalarından yola çıkarak ürün çeşitliliğinin öneminin altını çizmekte ve ürün çeşitliliği ile rekabet gücünün bir paranın iki yüzü olduğunu ifade etmektedir.

Bu kapsamda, ihracatta ürün çeşitliliğinin geliş̧imi bir yandan ihracatın artırılmasında, diğer yandan ihracat gelirlerinin istikrar kazanmasında önemli bir işleve sahiptir. Bu bölümde Türkiye'nin ihracatında yaşanan ürün çeşitliliği gini katsayısı ve geleneksellik endeksleri çerçevesinde incelenecektir.

\subsection{Gini Katsayısı}

İhracatın sektörler arasındaki dağılımının daha yüksek çeşitliliğe sahip, daha az yoğunlaşma ve 
uzmanlaşmaya tabi olup olmadığını test etmenin bir yolu gini katsayısıdır (Amiti ve Freund, 2008).

$G i n i=1-\frac{1}{n} \sum_{i}\left(k p a y_{i-1}+k p a y_{i}\right)$,

Eşitlik (1)'de, n sektör sayısı, i sektörün sıralaması (1 ile $n$ ) ve kpay, ise i sektörünün kümülatif payını göstermekteyken, Gini katsayısı ihracatta sektörel çeşitlenmenin bir göstergesi olmaktadır. Ilk 50, ilk 100 ve tüm sektörlerin dahil edildiği 3 farklı gini katsayısı, 1995, 2007 ve 2013 yılları için hesaplanmıştır. Grafik 2, gini katsayısındaki düşüş trendini göstermekte ve ürün çeşitliliğindeki artışa işaret etmektedir.

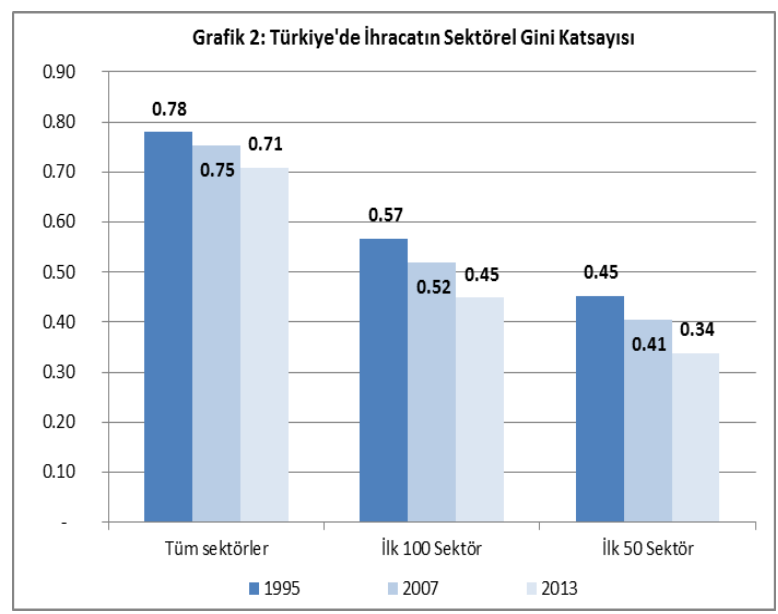

Türkiye'nin ihracatında ürün çeşitliliğinde artış gerçekleşip gerçekleşmediğini tespit etmek için doğrudan kümülatif paylar da kullanılabilmektedir. Bu amaçla sektörler ihracattan aldıkları paya göre büyükten küçüğe sıralanmış ve kümülatif payları hesaplanmıştır. Grafik 3'te yatay eksen 255 adet sektörü temsil etmekteyken, dikey eksen kümülatif payları göstermektedir. Çalışmanın inceleme dönemi olan 1995 ve 2013 yılları için çizilen kümülatif ihracat payları grafiğinde içe doğru kayma, ürün çeşitliliğinde bir artış olduğunu; bir başka ifadeyle ihracatta sektörel yoğunlaşmanın azaldığını ifade etmektedir. Nitekim ilk 30 sektörün ihracattan aldıkları kümülatif pay 1995 yılında \%68,5 iken, 2013 yılında \%58 olarak gerçekleşmiştir. Bu durum, ihracat sepeti bir bütün olarak düşünüldüğünde, çeşitliliğin artmış olduğunu teyit etmektedir. Çalışmanın devam eden kısımlarında ürün çeşitliliğindeki artışın yönü, şiddeti ve niteliği irdelenecektir.

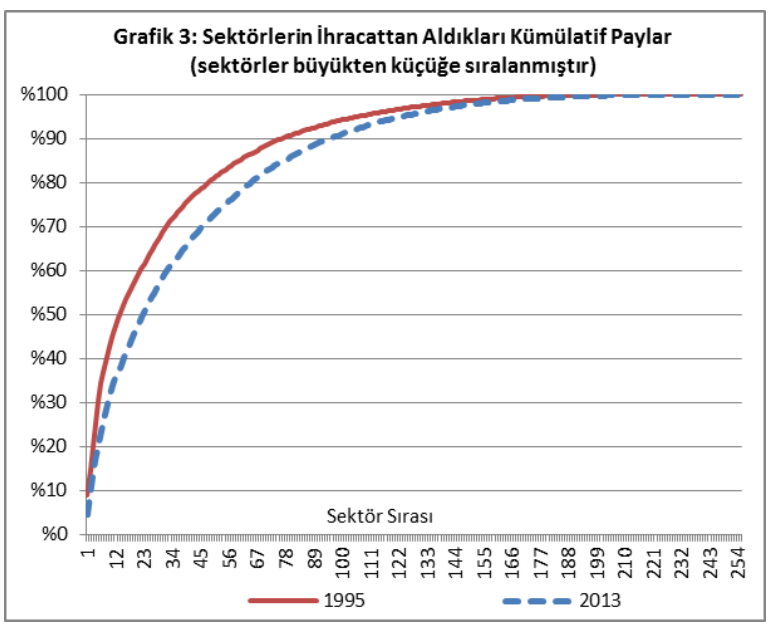

\subsection{Geleneksel Ve Geleneksel OImayan Sektörler}

İhracatta sektörel çeşitliliğin artışının daha detaylı incelenebilmesi için, sektörler geleneksel ve geleneksel olmayan olmak üzere ikiye ayrıştırılabilir (Erlat ve Erlat, 2012a). Söz konusu ayrıştırmanın yapılabilmesi için kullanılacak olan geleneksellik endeksinin hesaplanabilmesi amacıyla i sektörünün her bir yılda gerçekleştirdiği ihracat, sektörün dönem boyunca yaptığı ihracat toplamına oranlanmakta ve önceki yıllarla toplanarak kümülatif olarak ilerlemektedir. $X_{i t}$ i sektörünün t yılındaki ihracatını, $T$ ise dönem uzunluğunu göstermekteyken;

$\mathrm{c}_{\mathrm{is}}=\frac{\sum_{t=1}^{s} X_{i t}}{\sum_{t=1}^{T} X_{i t}}, \quad \mathrm{~s}=1, \ldots, \mathrm{T}$

Böylelikle $c_{\text {is' }}$ her bir dönemde i sektörü ihracatının, sektörün dönem boyunca (1995-2013) gerçekleştirdiği toplam ihracatındaki kümülatif payı göstermektedir. Dönem başında $c_{\text {is }}$ sıfıra yakın bir seviyedeyken, dönem ilerledikçe yükselmekte ve dönem sonunda 1'e ulaşmaktadır.

Geleneksellik endeksi, belirli bir dönem ele alındığında, hangi sektörlerin dönemin başında hangilerinin ise dönem sonuna doğru daha fazla ihracat gerçekleştirdiğinin tespit edilmesinden yola çıkmaktadır. Sektörel performanslar, tüm sektörlerin toplanması ile elde edilen toplam ihracattaki paylarından bağımsız olarak değerlendirilmektedir. Bir başka ifadeyle, sektörlerde dönem boyunca gerçekleştirilentoplamihracatın, ağırlıklıolarakdönem başında mı dönem sonunda mı gerçekleştirildiği tespit edilmektedir. Bu çerçevede, ihracatın ağırlıklı 
olarak dönem başında gerçekleştirilmesi durumunda sektör geleneksel olarak adlandırılacaktır.

Grafik 4'te, örnek olarak sunulan 2 sektörün dönem boyunca gerçekleştirdiği toplam ihracatın kümülatif gelişimi gösterilmektedir. Grafikten de görüldüğü gibi, Canlı Hayvanlar sektöründe ihracatın önemli bir kısmı dönem başlarında gerçekleştirilmişken, Demir Cevherleri sektöründe ihracat 2009 yılından sonra gerçekleştirilmiştir.

Her bir sektör için hesaplanan $\mathrm{c}_{\text {is }}^{\prime}$ lerin ortalaması, sektörlerin geleneksellik açısından karşılaştırılabilmesine olanak sağlamaktadır. Sektörleri "geleneksel" ve "geleneksel olmayan" şeklinde ikili bir sınıflamaya tabi tutabilmek için $\mathrm{t}$ istatistiği kullanılmıştır.

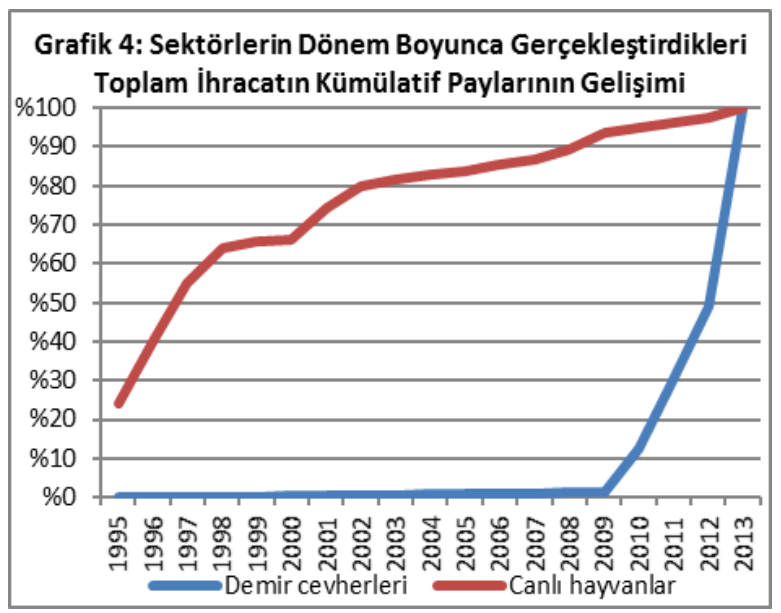

$\overline{C_{l s}}=\frac{\sum_{s=1}^{T} c_{i s}}{T}, \mathrm{i}=1, \ldots, \mathrm{N}$

$\overline{c_{\imath s}}=\frac{\sum_{s=1}^{T} c_{i s}}{T}, \mathrm{i}=1, \ldots, \mathrm{N}$

En geleneksel sektör, en yüksek $c_{\text {is }}$ ortalamasına sahip olacaktır. Sektörler $c_{i s}$ ortalamasına göre küçükten büyüğe sıralandıklarında, en az gelenekselden, en geleneksele doğru giden bir sıralama elde edilmiş olmaktadır.

$t_{i, j}=\frac{\overline{c_{\imath}}-\overline{c_{j}}}{\sqrt{\frac{\sigma_{i}^{2}}{T}+\frac{\sigma_{j}^{2}}{T}}}$ $\mathrm{t}$ istatistiği ile test edilen boş hipotez, sektörlerin ortalama $c_{\text {is }}$ değerlerinin farklı olmadığı anlamına gelmektedir. Boş hipotezin reddedilmesi durumunda, karşılaştırılan iki sektör için geleneksellik derecesinde (ortalama $c_{\text {is }}$ ) istatistikî olarak anlamlı ölçüde farklı oldukları sonucuna ulaşılacaktır.

Yapılan hesaplamalara göre 1995-2013 döneminde Türkiye'nin ihracat gerçekleştirdiği 255 faslın 118'i geleneksel, kalan 137 tanesi ise geleneksel olmayan şeklinde sınıflandırılmıştır.

Grafik 5, geleneksel olan ve olmayan sektörlerin ihracat içindeki payının gelişimini göstermektedir. Grafikten de görüldüğü gibi, geleneksel olmayan sektörlerin ihracat hacmimiz içindeki payı düzenli bir artış eğilimi göstermektedir. 2013 yılı itibariyle toplam ihracatın \%64,4'ü geleneksel olmayan ihracat kalemlerinden oluşmaktadır. Geleneksel olmayan sektörlerin toplam ihracat içindeki payının artışı, ürün çeşitliliğinin arttığına işaret etmektedir. Sektörlerin geleneksel olup olmamasına göre yapılan ayrıştırma, ilerleyen bölümlerde bir ayrıştırma ve analiz kriteri olarak kullanılacaktır.

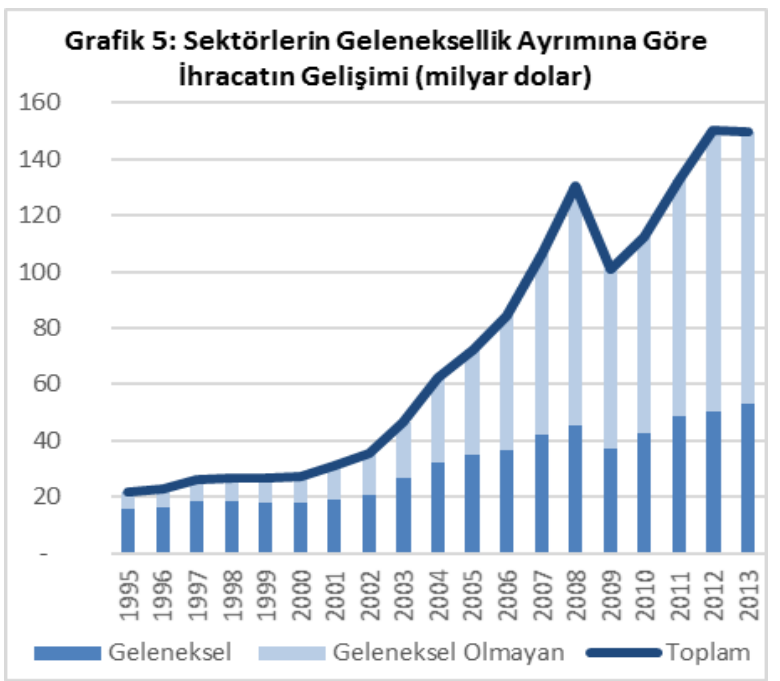

\section{3. İHRACATIN NITELIĞi}

İhracatın sektörel çeşitliliğinin artıyor olması, yapısal bir değişimi ima etmekte, buna karşın bu değişimin hangi yönde olduğuna ilişkin bir bilgi taşımamaktadır. Bu bölümde sektörel kompozisyonun değişiminin niteliği sektörlerin teknoloji kırılımları ile irdelenecektir.

Sektörler teknoloji yoğunluklarına göre tasnif edilirken, Hufbauer ve Chilas (1974), Yılmaz (2003) ve 
Özçelik ve Erlat (2013)'ta kullanılan SITC Rev3 tasnifine uygun beşli teknoloji ayrımı kullanılacaktır².

SITC 0, 2 (26 hariç), 3 (35 hariç), 4, 56

(Hammadde Yoğun Mallar - HYM)

SITC 26, 6 (62, 67, 68 hariç), 8 (87,88 hariç)

(Emek Yoğun Mallar - EYM)

SITC 1, 25, 53, 55, 62, 67, 68, 78

(Sermaye Yoğun Mallar - SYM)

SITC 51, 52, 54, 58, 59, 75, 76

(Taklidi Kolay Araştırma Yoğun Mallar-TKAYM)

SITC 57, 7 (75, 76, 78 hariç), 87, 88

(Taklidi Zor Araştırma Yoğun Mallar - TZAYM)

Teknoloji grupları tasnifiyle, geleneksel olan ve olmayan sektörlere ilişkin tasnif birleştirilerek, ihracatın sektörler bazında yapısal durumunun daha iyi ortaya konulabilmesi hedeflenmiştir. Böylelikle her bir teknoloji grubu kendi içinde geleneksel olan ve geleneksel olmayan olarak ikiye ayrılmış ve toplam ihracat incelenmiştir.

İhracat performansı, teknoloji gruplarına göre değerlendirildiğinde, geleneksel sektörlerin payının farklılaştığı görülmektedir (Grafik 6). Örneğin HYM ve EYM gruplarında, geleneksel olan ve olmayan sektörler, bu grupların toplam ihracatında yaklaşık yarı yarıya pay almaktadır. Nitekim, HYM grubunda gerçekleştirilen toplam 26,5 milyar dolarlık ihracatın 13,8 milyar doları geleneksel olmayan sektörler tarafından gerçekleştirilmiştir.

Buna karşın, TKAYM ihracatının \%36'sı, SYM ihracatının \%21,7'si, TZAYM ihracatının ise sadece \%4,6'sı geleneksel sektörler tarafından gerçekleştirilmektedir. TZAYM grubundaki ihracat performansına geleneksel olmayan sektörlerin verdiği katkının bu denli yüksek olması, sektörel çeşitliliğin artışında daha yüksek bir teknoloji grubunun ön plana çıkması çerçevesinde önemli addedilmektedir.
Grafik 7'de 1995 ile 2013 yılları için teknoloji gruplarının ihracattan aldıkları payın gelişimi gösterilmektedir. HYM ve EYM kategorilerinin inracattan aldıkları paylarda bir düşüş; bununla birlikte SYM, TKAYM, TZAYM kategorilerinin payında bir artış görülmektedir.

Grafik 6 ve Grafik 7 birlikte değerlendirildiğinde SYM ve TZAYM gruplarında geleneksel olmayan sektörlerin, bu grupların toplam ihracattaki paylarını da artırmalarını sağladığı anlaşılmaktadır. SYM grubunda geleneksel olmayan ve grup ihracatında en yüksek paya sahip ilk 3 sektörün motorlu yolcu taşıtları (781), demir veya çelikten filmaşin, çubuk ve profiller (676) ile motorlu taşıtların aksam ve parçaları (784) olduğu görülmektedir. TZAYM grubunda geleneksel olmayan ve grup ihracatında en yüksek paya sahip ilk 3 sektör ise, evlerde kullanılan elektrikli veya elektriksiz diğer makinalar (775), elektrik dağıtım donanımı (773) ve motorlar ve aksamı (713) olarak sıralanmaktadır.

Grafik 7'den de görüldüğü gibi Türkiye'nin inracat kompozisyonunda bir başka önemli değişim EYM grubundadır. EYM grubunun ihracattan aldığı payın değişimi, geleneksellik ayrımıyla birlikte değerlendirildiğinde daha keskin bir görünüm arz etmektedir. Nitekim, geleneksel EYM sektörlerinin toplam ihracattan aldıkları pay 1995'ten 2013'e $\% 43,3$ 'ten \%19,7'ye gerilemişken, geleneksel olmayan EYM sektörlerinin aldığı pay aynı dönemde \%6'dan \%15,7'ye yükselmiştir. Geleneksel olmayan EYM sektörlerinde kuyum (897), halı (659) ve mobilya (821) sektörleri payları yükselerek öne çıkarken, geleneksel EYM sektörlerinde, örülmüş olsun olmasın diğer giyim (845), örülmemiş giyim eşya ve aksesuarı (842), dokumaya elverişli maddelerden diğer hazır eşya ve takımlar (658) gibi tekstil ve konfeksiyon ile ilişkili sektörlerin paylarının azaldığı görülmektedir. Sektörlerin teknoloji gruplarına ve geleneksellik kırılımına göre ihracattan aldıkları paylar, çeşitli yıllar için Ek 1'deki tabloda sunulmaktadır.

${ }^{2}$ Teknoloji grupları tasnifinde, SITC Rev 3'ün 971 no'lu faslı olan "Parasal Olmayan Altın” yer almamakta, dolayısıyla son yıllarda tarihi ortalamaların oldukça üzerinde seyreden altın ihracatı verileri yapılan analizde büyük bir sapmaya neden olmamaktadır. 


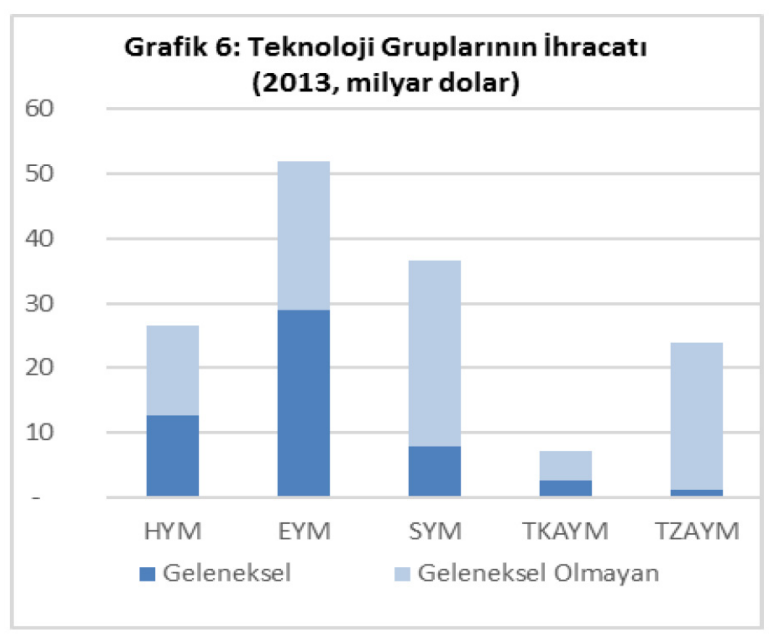

\section{REKABET GÜCÜ VE KARŞILAŞTIRMALI ÜSTÜNLÜKTEKI GELIŞiM}

Klasik (Ricardo'cu) ve Neoklasik ( $\mathrm{H}-\mathrm{O})$ yaklaşımlar, içlerinde farklılık barındırsa da, ticaretin varlığını karşılaştırmalı üstünlüğe dayandırmaktadırlar. Klasik teoride karşılaştırmalı üstünlüğün belirleyicisi emek verimliliği iken, Neoklasik teoride kaynakların göreli kıtlığı/bolluğu karşılaştırmalı üstünlüğün, dolayısıyla dış ticaretin ana belirleyici unsurudur. Bu nedenle, karşılaştırmalı üstünlük, uluslararası ticaretteki rekabetçiliğin ana nedeni olarak görülmektedir. Bununla birlikte, $\mathrm{H}-\mathrm{O}$ teoreminin önerdiği emek ve sermayenin göreli kıtlığı/bolluğundan yola çıkıldığında, sermaye stokunun ölçülmesi konusunda yaşanan sorunlardan dolayı karşılaştırmalı üstünlüğün ölçülmesi çok da kolay olmamaktadır (Özçelik ve Erlat 2013: 48). Balassa (1965) bu noktada ticaretin hem göreli fiyatları, hem de fiyat dışı faktörleri yansıttığını varsaymış ve böylelikle ticaret akımlarının incelenmesi ile karşılaştırmalı üstünlüklerin hesaplanabileceğini ifade etmiştir. Açıklanmış Karşılaştırmalı Üstünlükler (AKÜ)'in nasıl en doğru hesaplanabileceğine ilişkin mevcut tartışmaların ${ }^{33}$ yanında, Balassa (1965)'nın önerdiği yöntemin halen en yaygın kullanılan yöntem olduğu kabul edilmektedir (Dilek ve Gümüştekin 2012: 10).

$X_{i}$ Türkiye'nin i sektöründeki ihracatını, $X_{i w}$ ise dünyanın i sektöründeki toplam ihracatını gösterdiğinde, i sektörü için Türkiye'nin AKÜ'sü şu şekilde hesaplanabilecektir:

$A K \ddot{\mathrm{U}}_{i}=\frac{X_{i} / \sum_{i=1}^{N} X_{i}}{X_{i w} / \sum_{i=1}^{N} X_{i w}}$

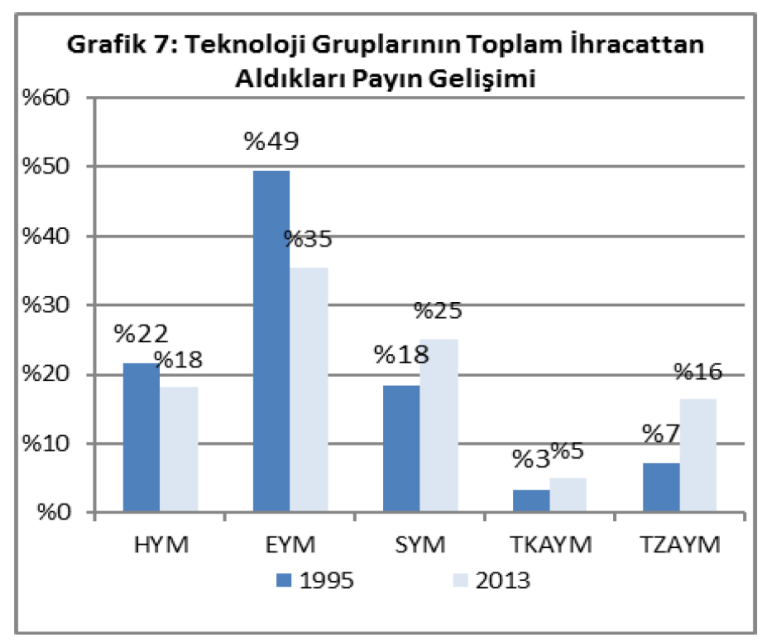

AKÜ'nün 1'den büyük olması, ülkenin o malda karşılaştırmalı üstünlüğe sahip olduğu anlamına gelmektedir. AKÜ>1 olan sektör sayısının yüksek olması çeşitliliğin arttığı ve ülkenin mevcut kaynaklarıyla daha fazla sektörde karşılaştırmalı üstünlüğe sahip olduğu anlamlarına gelmektedir. Dolayısıyla, AKÜ>1 koşulunu sağlayan sektör sayısı ülkenin ürün çeşitliliğinin bir göstergesi konumundayken, bu sektörlerin teknoloji gruplarına göre dağılımı, ülkenin ihracatının niteliğine ve rekabet gücünün gelişimine ilişkin bilgi sunacaktır.

Türkiye, 1995 yılı itibariyle 255 sektörün 71'inde karşılaştırmalı üstünlüğe sahip iken, 2013 yılına gelindiğinde bu sayı 96'ya ulaşmıştır. Türkiye, incelenen dönemde 35 adet sektörde karşılaştırmalı üstünlük kazanırken, 10 adet sektörde ise var olan üstünlüğünü kaybetmiştir. Türkiye'nin dünya piyasalarında rekabet gücünü kaybettiği sektörlerin yarısının HYM sektörü olduğu, söz konusu 10 sektörün 1995 yılı itibariyle toplam ihracattan \%3 pay aldığı, buna karşın 2013 yılında bu sektörlerin ihracattaki payının \%1'e gerilediği görülmektedir.

Tablo 2, Türkiye'nin AKÜ>1 olan sektör sayısının teknolojik dağılımını 1995 ve 2013 yılları için göstermektedir. Tablodan da görüldüğü gibi, Türkiye EYM'de karşılaştırmalı üstünlük sahibi olunan sektör sayısını 28'den 38'e, SYM'de 14'ten 20'ye, TKAYM'da 2'den 4'e, TZAYM'da ise 3'ten 11'e çıkarmış; buna karşın karşılaştırmalı üstünlük sahibi olunan sektör sayısı HYM'de 24'ten 23'e düşmüştür (Bkz. Ek1).

Grafik 8'de AKÜ>1 olan sektör sayısı teknoloji ve geleneksellik kırılımında sunulmaktadır. Türkiye'nin 
karşılaştırmalı üstünlüğe sahip olduğu sektör sayısı açısından EYM birinci konumda iken, EYM'yi, HYM ve SYM takip etmektedir. Araştırma Yoğun Mal (AYM) gruplarındaki zayıf performans dikkat çekse de, özellikle TZAYM grubunda, ihracatı dönem sonuna doğru yükselen (geleneksel olmayan) sektörlerde karşılaştırmalı üstünlük kazanılmış olması, teknoloji kompozisyonu açısından önemli ve umut verici görülmektedir.

Tablo 2: AKÜ>1 Sektörlerin Teknoloji Gruplarına Göre Dağılımı (1995-2013)

\begin{tabular}{|l|c|c|}
\hline & 1995 & 2013 \\
\hline Hammadde & 24 & 23 \\
\hline Emek Yoğun & 28 & 38 \\
\hline Sermaye Yoğun & 14 & 20 \\
\hline Kolay Taklit & 2 & 4 \\
\hline Zor Taklit & 3 & 11 \\
\hline Toplam & 71 & 96 \\
\hline
\end{tabular}

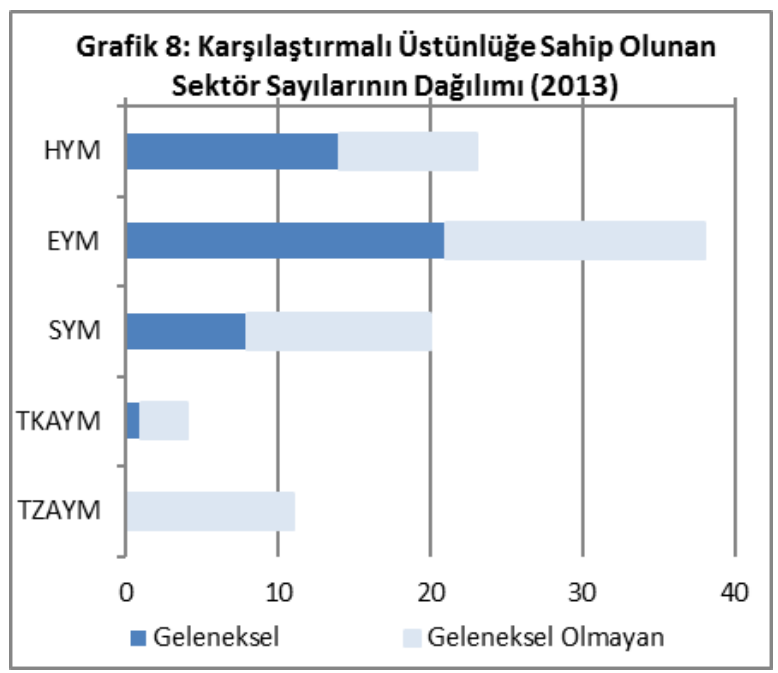

Bununla birlikte teknoloji kırılımına göre karşılaştırmalı üstünlük sahibi olunan sektör sayılarına dayalı yapılan analizler, her bir teknolojik kırılımda farklı sayıda sektör olması itibariyle yanıltıcı sonuçlar verebilecektir. Örneğin, HYM grubunda toplam 77 sektör yer alırken, TKAYM'da toplam 27 sektör yer almaktadır. Bu durumda HYM'de 20 sektörde karşılaştırmalı üstünlük sahibi olunması ile TKAYM'da 20 sektörde karşılaştırmalı üstünlük sahibi olunması aynı anlama, öneme ve gelişme potansiyeline işaret etmemektedir. Bu nedenle Grafik 9'da, Türkiye'nin her bir teknoloji grubunda karşılaştırmalı üstünlük sahibi olduğu sektör sayısının o teknoloji grubundaki sektör sayısına oranı kullanılmıştır. Örneğin 2013 yılında SYM grubunda Türkiye 20 sektörde karşılaştırmalı üstünlüğe sahip olmakla birlikte bu mal grubunda toplam 37 sektör yer almaktadır. Dolayısıyla Türkiye SYM'deki sektörlerin \%54'ünde (20/37) karşılaştırmalı üstünlüğe sahiptir. Radar grafiğin her bir köşesi bir teknoloji grubuna ilişkin söz konusu oranı temsil ederken, kesikli çizgi 1995 yılı, düz çizgi ise 2013 yılı değerlerini göstermektedir. Grafikten de görüldüğü gibi, Türkiye inceleme döneminde özellikle EYM ve SYM sektörlerine yönelmiş; bununla birlikte TKAYM ve TZAYM'da kaydedilen gelişme ise oldukça sınırlı kalmıştır. Bir başka ifadeyle EYM grubunun ihracattan aldığı pay geriliyor, ürün çeşitliliği artıyor olsa da, Türkiye ekonomisi EYM'de uzmanlaşmaya devam etmektedir.

\section{Grafik 9: Karşılaştırmalı Üstünlüğe Sahip Olunan Sektörlerin Toplam Sektör Sayısındaki Payı}

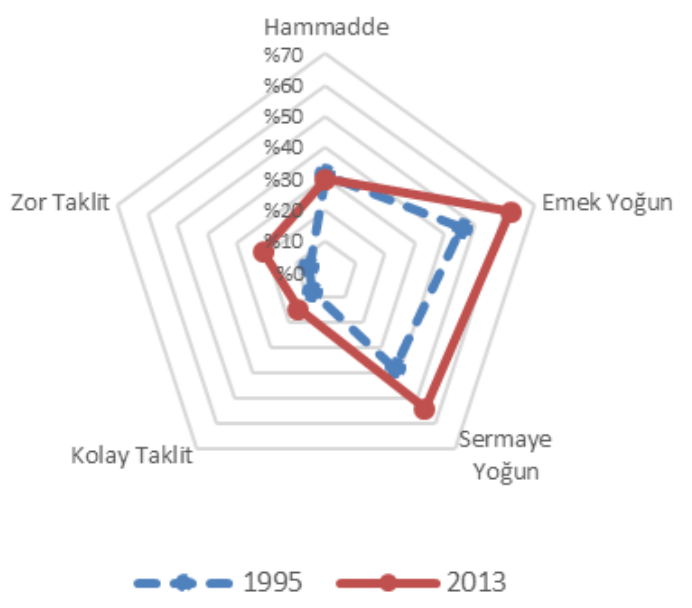

\subsection{Uluslararası Karşılaştırma}

Çalışmanın buraya kadar olan bölümünde 19952013 yıllar arasında Türkiye'nin ihracatında özellikle SYM,TKAYMveTZAYMgruplarının payının arttığı tespit edilmiştir. Bununla birlikte karşılaştırmalı üstünlükler çerçevesinde gelişim izlendiğinde Türkiye'nin özellikle EYM ve SYM'de gelişim sağladığı; AYM'deki ilerlemenin ise sınırlı olduğu ortaya koyulmuştur. Bu bölümde ise, karşılaştırmalı üstünlüklerin teknoloji gruplarına göre dağılımında Türkiye'nin seçilmiş ülkelere göre konumu incelenmiştir (Grafik 10-13). Karşılaştırmada temel alınan 8 ülke seçilirken kişi 
başına milli geliri ${ }^{4}$ Türkiye'ye görece yakın olan 4 ülke (Hırvatistan, Macaristan, Meksika, Malezya) ve görece uzak olan (hedef konum) 4 ülke ( $A B D$, Almanya, İspanya, İtalya) seçilmiştir.

Grafiklerden de görüldüğü gibi Türkiye'nin her iki ülke grubundan da ayrıştığı bir nokta bulunmaktadır. Türkiye, EYM ve SYM'de sergilediği gelişmeye ve TZAYM'de kaydettiği sınırlı ilerlemeye
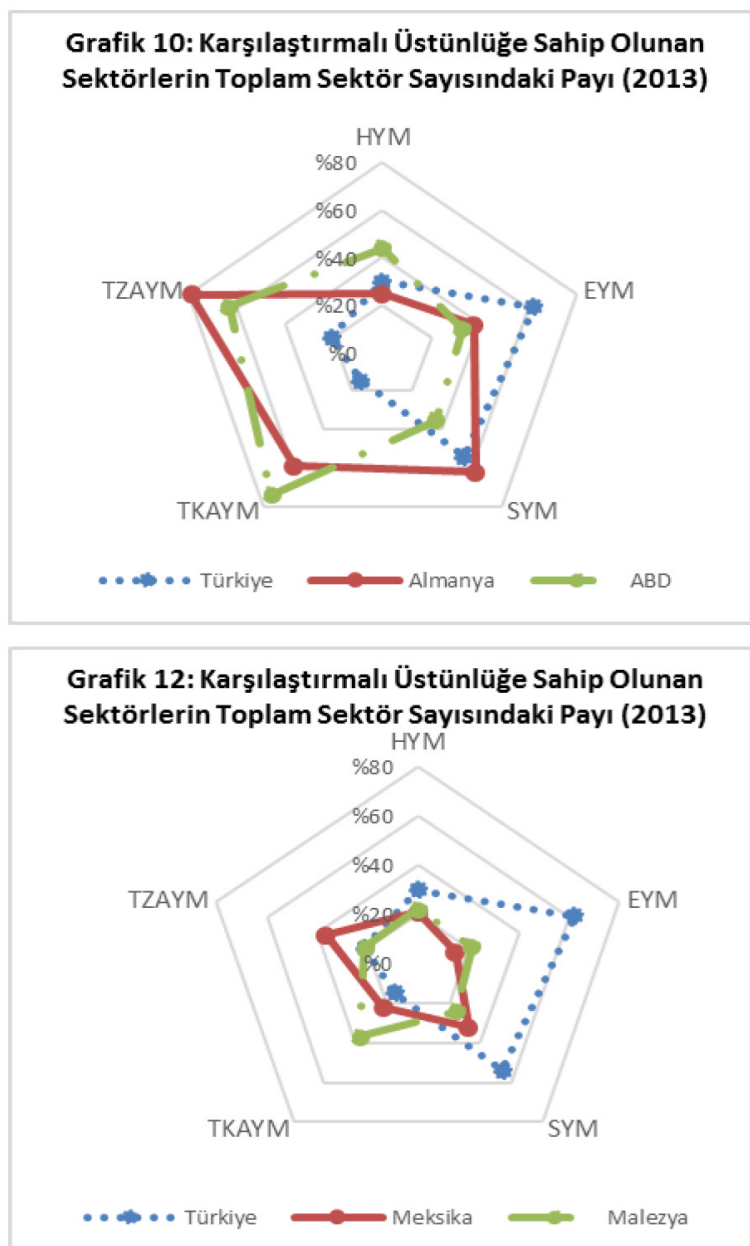

\section{PAZAR YOĞUNLUĞUNDAKI DEĞişiM}

Tek bir ülke veya ülke grubuna gerçekleştirilen ihracatın toplam ihracat içindeki payının çok yüksek olması, ihracat performansının söz konusu ülke veya ülke grubunun büyüme performansına olan bağımlılığını yükseltecek; böylelikle ihracatın sürdürülebilir artış trendi üzerinde tehdit oluşturabilecektir. karşın AYM grubunda oldukça zayıf bir performans sergilemektedir. İhracatın yapısal dönüşümünde son 19 yıllık performans, yönün EYM ve SYM'ye doğru olduğunu göstermektedir. Buna karşın, AYM'deki gelişme sınırlı ve yetersiz kalmıştır. Bu durum, AYM'deki sektörlerde gelişime odaklanan bir sanayi stratejisi belirlenmesi gerekip gerekmediği sorusunu akla getirmektedir ${ }^{5}$. Ancak bu soruya verilecek cevap, mevcut çalışmanın sınırlarını aşmaktadır.

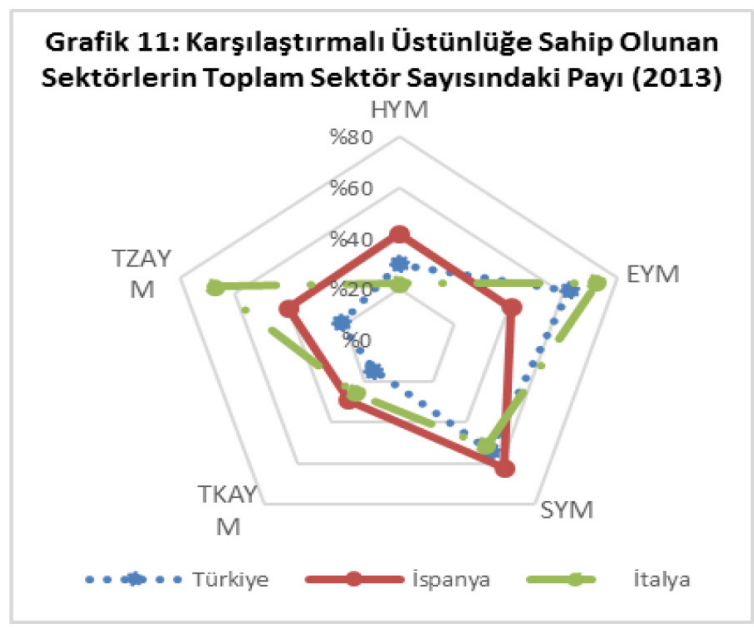

Grafik 13: Karşılaştırmalı Üstünlüğe Sahip Olunan Sektörlerin Toplam Sektör Sayısındaki

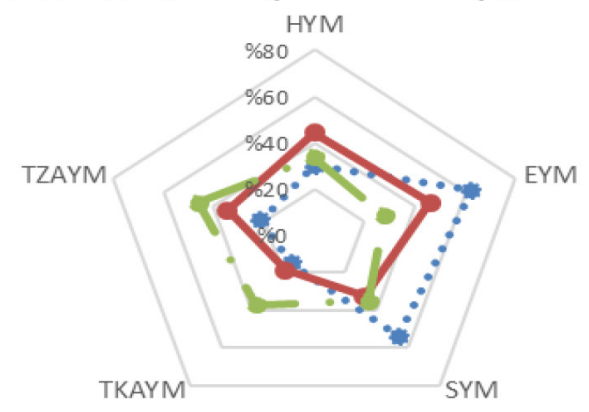

-.. Türkiye $\longrightarrow$ Mirvatistan $\longrightarrow$ Macaristan

Değer ve Genç (2010) yapmış oldukları çalışma sonucunda, 1980-2007 arası dönemde pazar çeşitliliğinin arttığını ve bu dönemde pazar çeşitliliği ile ihracat ve GSYH arasında olumlu bir ilişkinin var olduğunu tespit etmişlerdir. Çınar ve Göksel (2010: 49) Türkiye ekonomisinin ihracat performansını istikrar kavramı çerçevesinde, sektörel bazda pazar çeşitliliği ile incelemiş ve pazarlarını daha fazla çeşitlendirmiş 
olan sektörlerin daha istikrarlı bir ihracat performansı sergilediği tespitini yapmıştır. Bacchetta, Jansen, Piermartini ve Amurgo-Pacheco (2007) ise ihracat pazarlarındaki dalgalanmalardan daha az etkilenmek için pazar çeşitliliğin artırılmasının bir tampon görevi görebileceğini, dalgalanmaların bu şekilde yumuşatılabileceğini ifade etmektedir. AmurgoPacheco ve Pierola (2007: 10)'nın dünya genelinde farklı gelir gruplarına göre yaptıkları çalışmada ise gelişen ülkelerde çeşitlilik artışının gelişmiş ülkelere göre daha önemli olduğu, ihracat artışına daha fazla katkı sunduğu tespiti yer almaktadır.

Bu çerçevede değerlendirildiğinde, Türkiye'nin ihracatında yapısal dönüşümün bir ayağı sektörel çeşitlenme ise, bir diğer ayağı pazar çeşitlenmesidir. Türkiye ihracatının yapısal dönüşümüyle ilgili çalışmalardan bazıları, ihracat artışının yeni ürünlerin yeni pazarlara ya da eski ürünlerin eski pazarlara ihracatıyla mı gerçekleştiği sorusuna odaklanmaktadır (Türkcan, 2014; Türkcan ve Pişkin, 2014; Ekmen-Özçelik ve Erlat, 2013; Aldan ve Çulha, 2013). İhracatta sektörel çeşitlenmenin yanında pazar çeşitlenmesini de inceleyen Aldan vd. (2012), Türkiye ekonomisi için gerçekleştirdiği analizde küresel kriz sonrasında Türkiye ihracatının ürün bazında çeşitlilik artışının durduğunu, buna karşın ülkeler açısından yeni pazarlara açılmanın devam ettiğini ifade etmektedir. Aldan ve Çulha (2013), Türkiye'nin çeşitlilik artışından edindiği kazanımların, yeni üründen ziyade yeni pazarlara giriş ile elde edildiğini tespit etmiştir. Benzer şekilde Türkcan (2014), Türkiye'nin yüksek ihracat performansının coğrafi çeşitliliğin artırılması ile sağlandığını, buna karşın halen geleneksel pazarlarda önemli bir yoğunlaşmanın mevcut olduğunu vurgulamaktadır. Kaplan ve Tur (2013) ise pazar çeşitliliğindeki artışın Türkiye'nin ihraç mallarına yönelik daha yüksek oranlı dış talep artışı sağladığını; ihracatçıların karşılaştığı dış talep koşullarının daha olumlu olması yönünde katkı sağladığını göstermektedir.

Bu bölümde, konuyla ilgili yapılmış olan çalışmalardan farklı olarak, pazar çeşitliliğinin gelişimi geleneksellik ve teknoloji kırılımlarına göre incelenmiş, çalışma boyunca izlediğimiz mal gruplarının pazar yoğunluğunun ne yönde değiştiğinin değerlendirilmesi amaçlanmıştır. Böylelikle hem belli bir mal grubunda pazar yoğunluğunun (dolayısıyla pazar riskinin) yüksek olup olmadığının, hem de pazar çeşitliliğini artırarak ihracatı artırma imkanı kalıp kalmadığının tespit edilmesi amaçlanmıştır.

Yazında pazar veya sektörel yoğunluğun ölçülmesinde farklı endeksler kullanılmaktadır (Erlat ve Akyüz, 2001; Erlat ve Erlat, 2012b; Aldan vd. 2012; Illescas ve Jaramillo, 2011). Bu çalışmada, en yaygın kullanılan endekslerden biri olan Herfindahl Endeksi (HE) hesaplanmıştır.

$\mathrm{HE}$, her bir ülkenin ihracattaki payının karesinin alınması ve tüm ülkeler için her bir yılda elde edilen değerlerin toplanması yoluyla hesaplanmaktadır. Endeksteki azalış pazar çeşitliliğinin artması, bağımlıı̆ın azalması anlamına gelmektedir. HE, hem ihracat gerçekleştirilen tüm ülkelerin/ülke gruplarının hesaba katılması hem de büyük paya sahip ülkelerin daha yüksek ağırlığa sahip olması (paylarının karesi alındığı için) nedeniyle bu çalıma kapsamında, çeşitlilikteki değişimin ölçülmesi için iyi bir gösterge olarak kabul edilmiştir. Çalışmada m, ihracat gerçekleştirilen ülke sayısını gösterirken; $\mathrm{p}_{\mathrm{it}{ }^{\prime}} \mathrm{i}$ ülkesinin $\mathrm{t}$ zamanında ihracattan aldığı payı göstermekte ve $\mathrm{HE}_{\mathrm{t}}$ şu şekilde hesaplanabilmektedir:

Herfindahl Endeksi $\left(\mathrm{HE}_{\mathrm{t}}\right)=\sum_{i=1}^{m} p_{i t}^{2}$

Türkiye için yapılan hesaplamaların sonuçları Grafik 13-18'te sunulmaktadır. HE değerlerindeki azalmanın pazar yoğunluğunun azalması, pazar çeşitliliğinin artışı anlamına geldiği gözönüne alındığında, inceleme döneminde, tüm kırılımlarda pazar yoğunluğunun azaldığı görülmektedir.

Grafikler incelendiğinde aşağıdaki gözlemler yapılabilmektedir:

EYM grubunun geleneksel sektörlerinde pazar çeşitliliği istikrarlı ve anlamlı bir düşüş sergilemiştir

$\checkmark$ SYMgrubunun hem geleneksel hem de geleneksel olmayan sektörlerinde pazar çeşitliliği yüksektir,

$\checkmark$ TKAYM grubunun geleneksel sektörlerinde pazar çeşitliliğini artırma potansiyeli görülmektedir,

$\checkmark$ TZAYM grubunun geleneksel sektörlerinde HE'nin yüksek oynaklık sergilediği görülmekte, bu durumun, grup ihracat hacminin düşüklüğünden kaynaklandığı anlaşılmaktadır,

$\checkmark$ Geleneksel olmayan sektörlerde genel olarak pazar çeşitliliğinin yüksek olduğu görülmektedir, 
$\checkmark$ Gruplara geleneksellik ayrımı olmadan

bakıldığında, tüm gruplarda pazar çeşitliliğinin arttığı, pazar riskinin azaldığı görülmektedir.
Son olarak, pazar çeșitliliğindeki artışın 2011 yılından sonra ivme kaybettiği, yeni pazarlara açılma sürecinde bir durgunluk gerçekleştiği tespit edilebilmektedir.
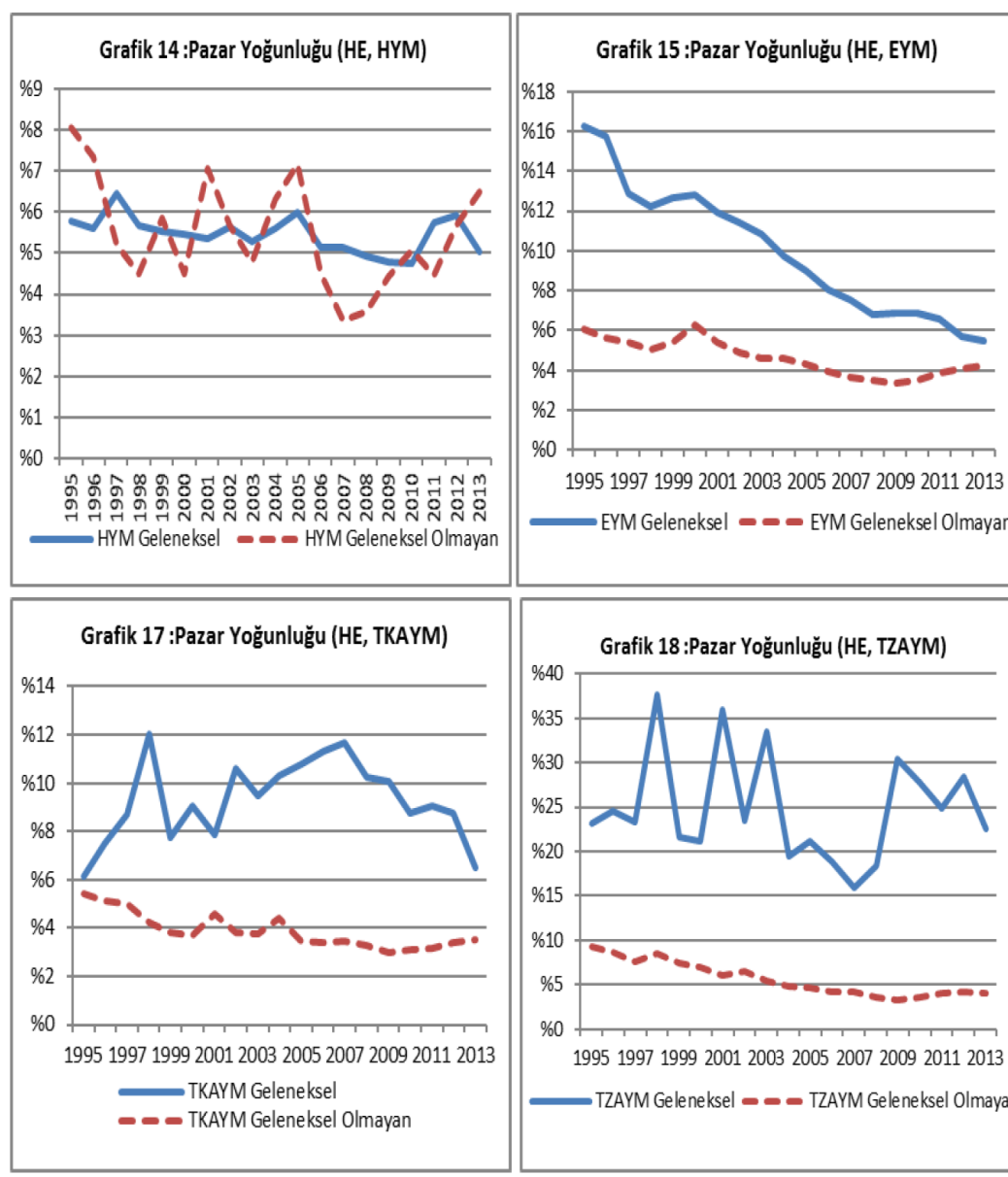
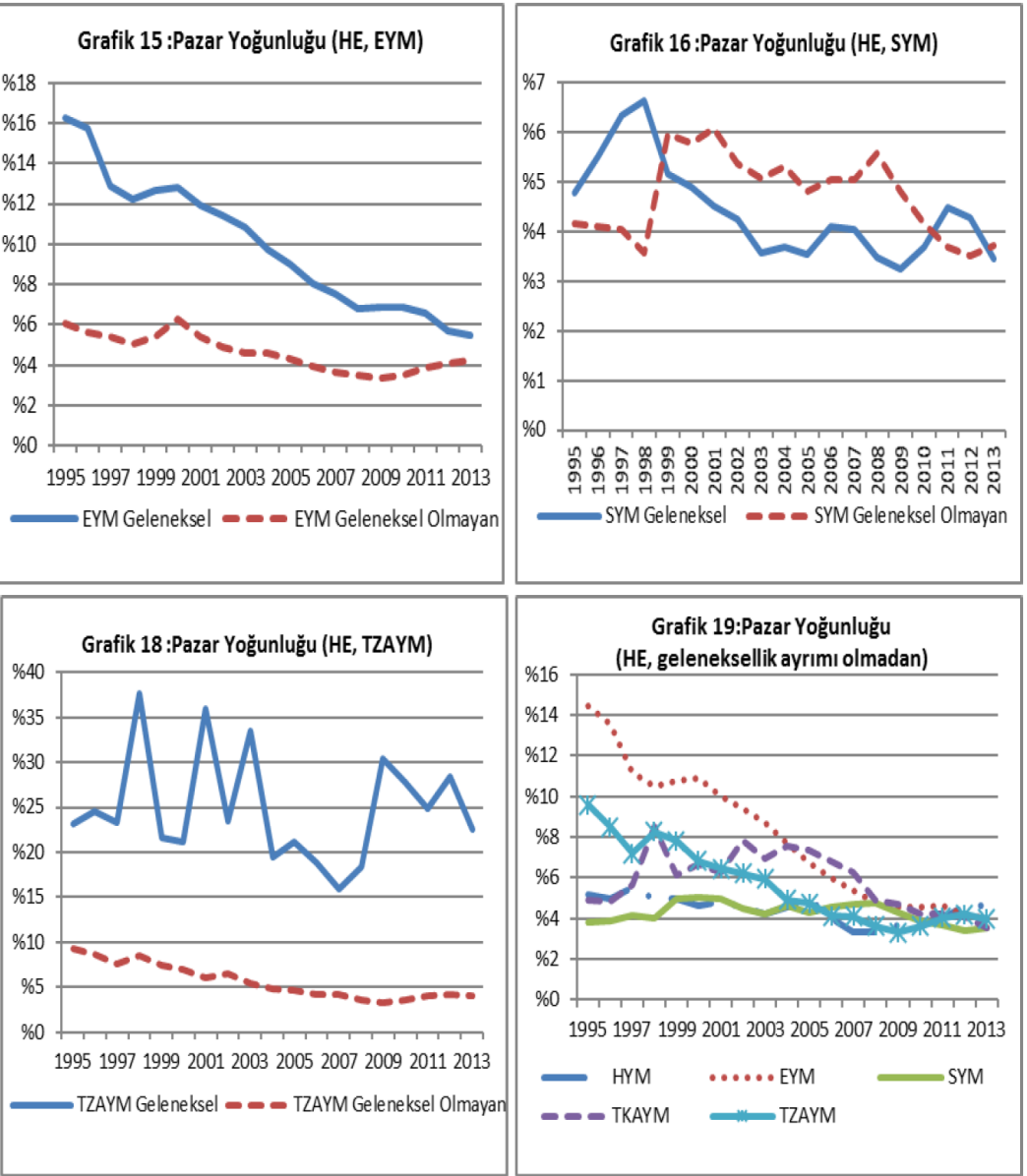

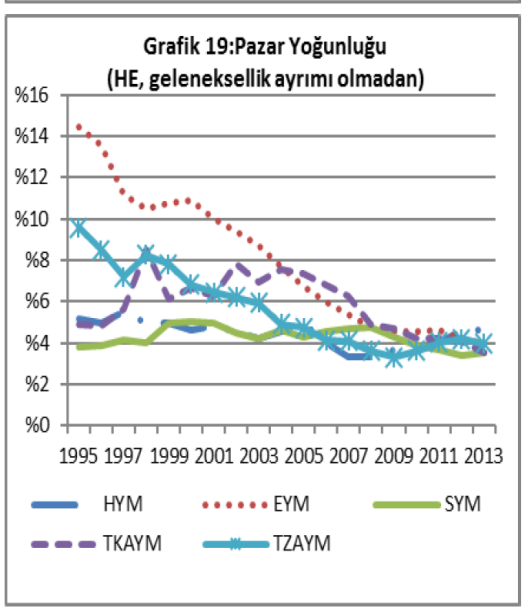

Herfindahl Endeksi ülkelerin dışında, geleneksellik ve teknoloji kırılımlarında ülke grupları ${ }^{6}$ için de ayrıca hesaplanmış ve benzer şekilde incelenen dönemde ülke gruplarının yoğunluğunun azaldığı görülmüştür. Buna karşın söz konusu göstergenin Avrupa ile ticari ilişkiler tarafından baskın olarak belirlendiğinin altının çizilmesi gerekmektedir. Ülke gruplarının paylarının gelişimi incelendiğinde ise aşağıdaki husular dikkat çekmektedir.

$\checkmark$ Avrupa'nın payının SYM grubunun (hem geleneksel hem de geleneksel olmayan) dışındaki tüm mal gruplarında düştüğü görülmektedir. Buna karşın SYM grubunun Avrupa'ya olan ihracatı inceleme dönemi boyunca yükselerek geleneksel mallarda \%50, geleneksel olmayan mallarda ise \%61 seviyesine çıkmıştır. Bu durum, SYM grubunun Avrupa'nın ekonomik performansına olan bağımlılığının arttığını göstermektedir. Bu husus SYM grubunun ülkeler bazında yoğunluğunun azalması (Grafik 16) ile birlikte değerlendirildiğinde grup ihracatının Avrupa ülkeleri arasındaki dağılımının daha çeşitli dağıldığı yönünde anlaşılmaktadır.

$\checkmark$ EYM grubundan (hem geleneksel hem de geleneksel olmayan) Amerika'ya gerçekleştirilen ihracat 1995-2000 döneminde artarken, 2000'den sonra istikrarlı şekilde azalmaktadır.

$\checkmark$ Genel olarak değerlendirildiğinde, Avrupa'nın payı inceleme döneminde azalmış olsa da, 
belirleyiciliğini sürdürmektedir. İhracatta Afrika ve Asya kıtalarının payının arttığı, bu bağlamda pazar çeşitliliğinin arttığı görülmektedir.

Avrupa'nın ihracatımızda yüksek pay almaya devam ediyor olmasına karşın, ülkeler bazında hesaplanan $\mathrm{HE}$, Avrupa içi ülkeler arasında daha dengeli bir dağılım olduğu sinyalini vermektedir. Kaplan ve Tur (2013)'da toplulaştırılmış ihracat verilerinde yapılan bu tespit, bu çalışmada teknoloji grubu ve geleneksellik kırılımlarında da teyit edilmiş olmaktadır.

\section{SONUÇ}

Illgili yazında Türkiye ihracatının yapısı, yapının dönüşümü ve rekabet gücü, genellikle $A B, B R I C$ ülkeleri veya Orta Doğu ülkeleri ile veya bu ülke gruplarındaki rakiplerle karşılaştırma çerçevesinde ele alınmıştır. Bu çalışmanın odak noktası ise Türkiye ihracatının 1995-2013 döneminde yaşadığı dönüşümün ortaya koyulmasıdır.

Bu çerçevede çalışmada ürün çeşitliliğinin arttığı gözlemlenmiştir. Teknoloji gruplarının ihracattan aldıkları paylara bakıldığında SYM veTZAYM grubunda dikkate değer bir artış yaşandığı; buna karşın EYM grubunun payında bir azalma olduğu görülmektedir. SYM grubundaki yükselişin itici gücünün otomotiv ve demir çelik ile ilişkili alt sektrölerden oluştuğu, TZAYM grubu performansının daha geniş bir sektör sepetine yayıldığı görülmektedir. Bununla birlikte EYM grubunun ihracattan aldığı payın düşüşündeki faktörün geleneksel mal grubunda yer alan tekstil ile bağlantılı sektörler olduğu görülmektedir. Nitekim inceleme döneminde geleneksel EYM'nin toplam inracatta aldığı pay \%43,2'den \%19,7'ye gerilemiştir. Buna karşın kuyum, halı ve mobilya gibi geleneksel olmayan EYM sektörlerinin toplam ihracattaki payı $\% 6$ 'dan \%15,7'ye yükselmiştir.
Bununla birlikte EYM'nin ihracattaki payı düşse de, yapısal dönüşümün yönü karşılaştırmalı üstünlükler temelinde değerlendirildiğinde, Türkiye'nin EYM grubunda uzmanlaşma eğilimini devam ettirdiği görülmektedir. Türkiye, EYM ve SYM'de 1995'e göre daha fazla uzmanlaşmış durumdayken, TZAYM grubunda sınırlı bir ilerleme kat etmiştir. Bu durum, kaynakların düşük teknolojik yoğunluklu alanlara ayrılmaya devam ettiğine işaret etmektedir.

Çalışmada Türkiye'nin karşılaştırmalı üstünlükler temelindeki mevcut konumu, benzer ve görece gelişmiş ülkeler ile karşılaştırılmış ve AYM gruplarında yetersiz bir performans sergilendiği tespit edilmiştir. Türkiye ihracatının 19 yıllık dönüşümü incelendiğinde, AYM grubundaki gelişmenin kayda değer ölçüde gerçekleşmemiş olması, bu gruptaki sektörlere odaklanan bir stratejiye intiyaç olup olmadığı, varsa bu stratejide hangi sektörlere odaklanılması gerekeceği sorularını akla getirmektedir.

Kalkınmanın, kaynakların daha yüksek verimliliğe sahip sektörlere doğru yöneldiği bir süreç olduğu kabul edildiğinde (Rodrik, 2011), Türkiye'nin sektör temelli dinamik bir strateji geliştirmeye intiyacı olduğu değerlendirilmektedir. Bu çerçevede ilk önce ülkenin mevcut gelişme kapasitesi ve eğilimine uygun olan sektörlerin belirlenmesi, sonraki adımda ise bu sektörlerin önünün açılması için ihtiyaç duyulan politikaların sektörler bazında ortaya koyulması gerekecektir. Bahsi geçen hususlar, ihtiyaç duyulan politikanın tespit ve tasarımının ileri adımları olarak değerlendirilmekte ve başka araştırmalar için önemli birer soru olarak görülmektedir.

Son olarak çalışmada teknoloji ve geleneksellik kırılımlarında incelenen pazar yoğunluğu göstergesi çeşitlilik artışına işaret etmekte; bu durum pazar riskinin azaldığı anlamına gelmektedir. Bununla birlikte pazar çeşitliliğindeki artışın 2011 yılı sonrasında ivme kaybettiği görülmektedir.

\section{KAYNAKLAR}

Aldan, A., Aydın, M.F., Çulha, O.Y., Sunel, E. Ve Taşkın, T. (2012) "ihracatta Bölgesel ve Sektörel Çeşitlenme" TCMB Ekonomi Notları, 18 Temmuz.

Aldan, A. Ve Çulha, O.Y. (2013) "The Role Of Extensive Margin in Exports of Turkey: A Comparative Analysis" CBRT Working Paper, 13(32), August.
Amıtı, M. Ve Freund, C. (2008) “The Anatomy of China's Export Growth" The World Bank Policy Research Working Paper, No. 462, 8, May.

Amurgo-Pacheco, A. Ve Pierola, M.D. (2008) “Patterns of Export Diversification in Developing Countries: Intensive and Extensive Margins" HEI Working Paper (20). 
Aytemiz, S. (2011) "Türkiye İhracatının Sabit Piyasa Payı Yöntemi ile Analizi" Afyon Kocatepe Üniversitesi IïBF Dergisi, (C.XIII, S II).

Bacchetta, M., Jansen, M., Piermartını, R. Ve AmurgoPacheco A. (2007) "Export Diversification as an Absorber of External Shocks" 2007, August.

Balassa, B. (1965) "Trade Liberalisation and 'Revealed' Comparative Advantage" Manchester School, 33, 99123.

Çınar, Y. Ve T. Göksel (2010) "Ihracatta Bölgesel Çeşitlenme ve İstikrar" Ankara Üniversitesi SBF Dergisi, 65(2), 29-57.

Değer, M.K. Ve M.C. Genç (2010) "İhracatta Ülke Çeşitliliğinin Toplam İhracat ve Hasıla Üzerine Etkisi: Türkiye Ekonomisi Üzerine Eş-Bütünleşme ve Nedensellik Testleri (1980-2007)" Akdeniz i.i.B.F. Dergisi, (20), 66-85.

Dilek, S. Ve Gümüştekin, C. (2012) "R\&D Intensive Goods Trade and Compettiveness of Turkey in the European Union Market" Discussion Paper, Turkish Economic Association, No. 2012/24

Ekmen-Özçelik, S. Ve Erlat G. (2013) “What Can We Say About Turkey and its Competitors in the EU Market? An Analysis by Extensive and Intensive Margins" Topics in Middle Eastern and African Economies, Vol.15, No.1, May.

Erkan, B. (2012) “BRIC Ülkeleri ile Türkiye'nin İhracat Uzmanlaşma ve Rekabet Düzeylerinin Karşılaştırmalı Analizi" Ekonomi ve Sosyal Araştırmalar Dergisi, Bahar, Cilt 8, Yıl 8, Sayı 1, 8: 101-131.

Erlat, G. Ve Akyüz O. (2001) "Country Concentration of Turkish Exports and Imports Over Time" Economics Web Institutes, www.luc.edu/orgs/meea/volume3/ gerlat.pdf (14.08.2013).

Erlat, G. Ve Erlat H. (2005) “Do Turkish Exports Have a Comparative Advantage with Repect to the European Union Market, 1999-2000" Topics in Middle Eastern and North African Economies, Electronic Journal, Volume 7, September.

Erlat, G. Ve Erlat H. (2012a), "The Comparative Advantage of Turkish Exports Vis-a-Vis The European Union and OECD Countries, 1990-2000" Ekonomik Yaklaşım, Cilt:23, Özel Sayı, ss.77-106.

Erlat, G. Ve Erlat H. (2012b) “Türkiye'nin Orta Doğu Ülkeleri ile Olan Ticareti, 1990-2002" Türkiye Ekonomi Kurumu Tartışma Metni, 2012/26, Mayıs.
HufbauerVe Chilas, (1974) "Specialization by Industrial Countries; Extent and Consequences" içinde Gierch, International Division of Labor, s.3-38.

Illescas J. Ve Jaramillo C.F. (2011) "Exporth Growth and Diversification The Case of Peru" The World Bank Policy Research Working Paper, (5658), November.

Kaplan, H. Ve Tur, F. (2013) "ihracatta Pazar Kompozisyonundaki Değişimin Dış Talep Göstergesine Etkisi" Ekonomik Yaklaşım, 24 (86), s.2953

Lın, J. Ve Chang, H.J. (2009) "Should Industrial Policy in Developing Countries Conform to Comparative Advantage or Defy it? A Debate Between Justin Lin and Ha-Joon Chang" Development Policy Review, 27 (5), s.483-502.

Özçelik, S.E. Ve Erlat G. (2013) “Turkey's Comparative Advantages and Dynamic Market Positioning in the EU Market" Topics in Middle Eastern and African Economies, Vol.15, No.2, September, pp 42-70.

Rodrik, D. (2011) "The Future of Economic Convergence", NBER Working Paper Series, 17400, September

Türkcan, K. (2014) "Investigation the Role of Extensive Margin, Intensive Margin, Price and Quantity Components on Turkey's Exporth Growth During 1998-2011" Turkish Economic Association Discussion Paper, 2014/2, February.

Türkcan, K. Ve Pişkin, E. (2014) “Ticaret Anlaşmalarının Türkiye'nin Ihracat Dinamiğine Etkisi: Yaygın ve Yoğun Ticaret" Türkiye Ekonomi Kurumu Tartışma Metni, 2014/10, Kasım.

Utkulu, U.VeSeymen, D. (2004)“Revealed Comparative Advantage and Compettiveness: Evidence for Turkey vis-a-vis the EU/15" presented at the European Trade Study Group $6^{\text {th }}$ Annual Conference, ETSG, September.

Vergil H. Ve Yıldırım, E. (2006) "AB-Türkiye Gümrük Birliği'nin Türkiye'nin Rekabet Gücü Üzerindeki Etkileri" Erciyes Üniversitesi IiBF Dergisi, Sayı 26, Ocak - Haziran, ss.1-21.

Yılmaz, B. (2003) “Turkey's Competitiveness in the European Union: A Comparison with Five Candidate Countries - Bulgaria, The Czech Republic, Hungary, Poland, Romania- and the EU15" Ezoneplus Working Paper, No.12. 


\begin{tabular}{|c|c|c|c|c|c|c|c|c|c|c|c|}
\hline \multirow[b]{2}{*}{ Geleneksellik } & \multirow[b]{2}{*}{$\begin{array}{l}\text { Teknoloji } \\
\text { Grubu }\end{array}$} & \multirow[b]{2}{*}{$\begin{array}{c}\text { Sektör } \\
\text { Kodu }\end{array}$} & \multirow[b]{2}{*}{ Sektör Adı } & \multicolumn{4}{|c|}{$\begin{array}{l}\text { Sektörün Ihracattan Aldı̌̆ı Pay } \\
\text { (2013 Payına Göre Sıralanmış̧tı) }\end{array}$} & \multicolumn{4}{|c|}{$\begin{array}{c}\text { Karşılaş̧ırmalı Üstünlük Var mı ? } \\
\text { (Varsa 1, Yoksa 0) }\end{array}$} \\
\hline & & & & 1995 & 2003 & 2007 & 2013 & 1995 & 2003 & 2007 & 2013 \\
\hline \multirow{42}{*}{ 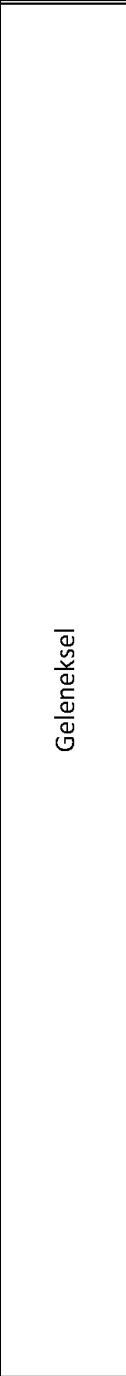 } & \multirow{42}{*}{ 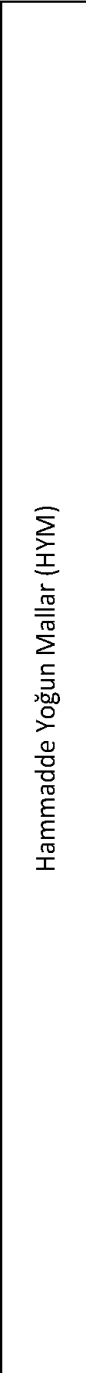 } & 57 & Taze/kuru meyve ve kabuklu yemişler, bunların karışımları & $\% 5.61$ & $\% 2.90$ & $\% 2.49$ & $\% 2.67$ & 1 & 1 & 1 & 1 \\
\hline & & 48 & Ekmekçilik ve pastacılık ürünleri, makarna & $\% 1.02$ & $\% 0.51$ & $\% 0.49$ & $\% 1.04$ & 1 & 1 & 1 & 1 \\
\hline & & 58 & Sebze ve meyveden hazırlanmış konserveler & $\% 1.08$ & $\% 0.72$ & $\% 0.72$ & $\% 0.71$ & 1 & 1 & 1 & 1 \\
\hline & & 54 & Buharda veya suda kaynatılıış, pişirilmiş, meyve ve başka sebzeler & $\% 1.68$ & $\% 0.98$ & $\% 0.77$ & $\% 0.68$ & 1 & 1 & 1 & 1 \\
\hline & & 421 & Bitkisel sıvı yağlar & $\% 0.91$ & $\% 0.47$ & $\% 0.19$ & $\% 0.59$ & 1 & 1 & 1 & 1 \\
\hline & & 56 & Kurutulmuş sebzeler, sebze ve meyvelerin unu, ezmesi, tozları & $\% 1.39$ & $\% 0.76$ & $\% 0.53$ & $\% 0.51$ & 1 & 1 & 1 & 1 \\
\hline & & 278 & Diğer ham mineraller & $\% 1.02$ & $\% 0.33$ & $\% 0.26$ & $\% 0.49$ & 1 & 1 & 1 & 1 \\
\hline & & 73 & Çikolata ve kakao içeren diğer maddeler & $\% 0.37$ & $\% 0.28$ & $\% 0.31$ & $\% 0.37$ & 1 & 1 & 1 & 1 \\
\hline & & 62 & Șeker mamülleri & $\% 0.86$ & $\% 0.27$ & $\% 0.23$ & $\% 0.34$ & 1 & 1 & 1 & 1 \\
\hline & & 431 & Kimyasal ișlem görmüş bitkisel ve hayvansal katı/sıvı yağ|lar, mumlar & $\% 0.52$ & $\% 0.05$ & $\% 0.08$ & $\% 0.24$ & 1 & 0 & 1 & 1 \\
\hline & & 59 & Meyve suları (üzüm şırası dahil) sebze suları & $\% 0.31$ & $\% 0.16$ & $\% 0.15$ & $\% 0.13$ & 1 & 1 & 1 & 1 \\
\hline & & 91 & Margarin & $\% 0.65$ & $\% 0.20$ & $\% 0.11$ & $\% 0.13$ & 1 & 1 & 1 & 1 \\
\hline & & 288 & Metalleri/metal bileşiklerini içeren kül ve kalıntılar & $\% 0.09$ & $\% 0.07$ & $\% 0.10$ & $\% 0.11$ & 0 & 0 & 0 & 0 \\
\hline & & 61 & Şeker, bal ve şeker melası & $\% 0.05$ & $\% 0.22$ & $\% 0.06$ & $\% 0.11$ & 0 & 1 & 0 & 0 \\
\hline & & 75 & Biber ve diĕer baharatlar & $\% 0.18$ & $\% 0.11$ & $\% 0.08$ & $\% 0.09$ & 1 & 1 & 1 & 1 \\
\hline & & 292 & Başka yerde belirtilmeyen bitk,sel ürünler (Yenilmeye elverișli olmayan) & $\% 0.26$ & $\% 0.11$ & $\% 0.07$ & $\% 0.09$ & 0 & 0 & 0 & 0 \\
\hline & & 223 & Diğer yağlı tohum ve meyveler, un ve küspeleri & $\% 0.05$ & $\% 0.07$ & $\% 0.05$ & $\% 0.06$ & 1 & 1 & 1 & 1 \\
\hline & & 41 & Buğday ve mahlut & $\% 0.10$ & $\% 0.00$ & $\% 0.01$ & $\% 0.05$ & 0 & 0 & 0 & 0 \\
\hline & & 72 & Kakao & $\% 0.01$ & $\% 0.11$ & $\% 0.04$ & $\% 0.05$ & 0 & 0 & 0 & 0 \\
\hline & & 291 & Insan tarafından yenilmeye elverişli olmayan hayvansal ürünler & $\% 0.20$ & $\% 0.10$ & $\% 0.03$ & $\% 0.04$ & 1 & 1 & 0 & 0 \\
\hline & & 232 & Sentetik kauçuk, taklit kauçuk, rejenere kauçuk ve atıkları (il şekillerde) & $\% 0.07$ & $\% 0.01$ & $\% 0.01$ & $\% 0.04$ & 0 & 0 & 0 & 0 \\
\hline & & 37 & Balıklar, kabuklu hayvanlar ve yumşakçaların konserveleri & $\% 0.19$ & $\% 0.06$ & $\% 0.03$ & $\% 0.03$ & 1 & 0 & 0 & 0 \\
\hline & & 36 & Kabuklu hayvanlar, yumuşakçalar & $\% 0.10$ & $\% 0.07$ & $\% 0.05$ & $\% 0.02$ & 0 & 0 & 0 & 0 \\
\hline & & 248 & Ahşap demiryolu veya tramvay traversleri & $\% 0.11$ & $\% 0.04$ & $\% 0.03$ & $\% 0.02$ & 0 & 0 & 0 & 0 \\
\hline & & 74 & Çay ve paraguay çayı & $\% 0.02$ & $\% 0.02$ & $\% 0.01$ & $\% 0.01$ & 0 & 0 & 0 & 0 \\
\hline & & 1 & Canlı havvanlar & $\% 0.61$ & $\% 0.02$ & $\% 0.01$ & $\% 0.01$ & 1 & 0 & 0 & 0 \\
\hline & & 277 & Sanayide kullanılan elmas, sünger taşı, zımpara taşı vs. & $\% 0.06$ & $\% 0.02$ & $\% 0.01$ & $\% 0.01$ & 1 & 1 & 1 & 0 \\
\hline & & 411 & Hayvansal katı veya sıvı yağlar & $\% 0.03$ & $\% 0.01$ & $\% 0.00$ & $\% 0.01$ & 0 & 0 & 0 & 0 \\
\hline & & 285 & Aluminyum cevherleri ve aluminyum oksit & $\% 0.05$ & $\% 0.02$ & $\% 0.02$ & $\% 0.00$ & 0 & 0 & 0 & 0 \\
\hline & & 211 & Ham deriler (post ve kürk dışında) & $\% 0.02$ & $\% 0.07$ & $\% 0.02$ & $\% 0.00$ & 0 & 0 & 0 & 0 \\
\hline & & 422 & Diğer bitkisel sıvı yağlar & $\% 0.04$ & $\% 0.01$ & $\% 0.00$ & $\% 0.00$ & 0 & 0 & 0 & 0 \\
\hline & & 247 & 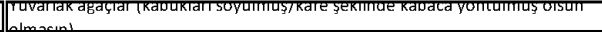 & $\% 0.02$ & $\% 0.01$ & $\% 0.00$ & $\% 0.00$ & 0 & 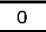 & 0 & 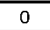 \\
\hline & & 23 & Tereyaĕı̆, süt esasısı katı-sıvı yaŭlar & $\% 0.00$ & $\% 0.00$ & $\% 0.00$ & $\% 0.00$ & 0 & 0 & 0 & 0 \\
\hline & & 325 & Kok ve sömikok (taskömürü, linvit ve turbdan) karni kömürü & $\% 0.00$ & $\% 0.00$ & $\% 0.01$ & $\% 0.00$ & 0 & 0 & 0 & 0 \\
\hline & & 342 & Iıvilaștırılmış propan ve bütan gazı & $\% 0.00$ & $\% 0.01$ & $\% 0.02$ & $\% 0.00$ & 0 & 0 & 0 & 0 \\
\hline & & 321 & Taş kömürü & $\% 0.00$ & $\% 0.00$ & $\% 0.00$ & $\% 0.00$ & 0 & 0 & 0 & 0 \\
\hline & & 11 & SIğı̆ı eti-taze/soğutulmuș/dondurulmuș & $\% 0.00$ & $\% 0.00$ & $\% 0.00$ & $\% 0.00$ & 0 & 0 & 0 & 0 \\
\hline & & 45 & Buğday, pirinç, arpa ve mısır dışı tahıllar & $\% 0.00$ & $\% 0.00$ & $\% 0.00$ & $\% 0.00$ & 0 & 0 & 0 & 0 \\
\hline & & 212 & Ham postlar (bütün halde) & $\% 0.00$ & $\% 0.00$ & $\% 0.00$ & $\% 0.00$ & 0 & 0 & 0 & 0 \\
\hline & & 43 & Arpa & $\% 0.21$ & $\% 0.09$ & $\% 0.04$ & $\% 0.00$ & 1 & 1 & 1 & 0 \\
\hline & & 333 & Petrol vas̆ları ve bitümenli minerallerden elde edilen yağlar (ham petrol) & $\% 0.01$ & $\% 0.01$ & $\% 0.00$ & $\% 0.00$ & 0 & 0 & 0 & 0 \\
\hline & & 286 & Uranyum ve Toryum Cevheri & $\% 0.00$ & $\% 0.00$ & $\% 0.00$ & $\% 0.00$ & 0 & 0 & 0 & 0 \\
\hline \multirow{22}{*}{$\begin{array}{l}\bar{d} \\
\frac{\Delta}{\Delta} \\
\frac{c}{\Delta} \\
\stackrel{0}{0}\end{array}$} & \multirow{22}{*}{ 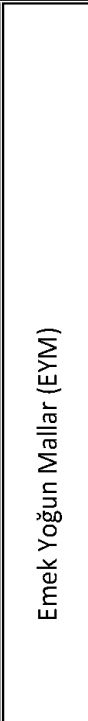 } & 845 & Örülmüş olsun olmasın diğer giyim eşyası & $\% 9.05$ & $\% 7.93$ & $\% 4.66$ & $\% 3.74$ & 1 & 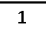 & 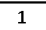 & 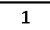 \\
\hline & & 842 & Kadın/kız çocuklar için örülmemiş givim eşvası ve aksesuarları & $\% 5.34$ & $\% 4.89$ & $\% 3.04$ & $\% 2.21$ & 1 & 1 & 1 & 1 \\
\hline & & 658 & Dokumava elverişli maddelerden diǧer hazır eşva ve takımlar & $\% 2.44$ & $\% 3.48$ & $\% 1.99$ & $\% 1.49$ & 1 & 1 & 1 & 1 \\
\hline & & 841 & Erkek/erkek çocuklar için örülmemiş giyim eşyası ve aksesuarlar & $\% 3.90$ & $\% 2.94$ & $\% 1.92$ & $\% 1.49$ & 1 & 1 & 1 & 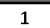 \\
\hline & & 844 & Kadın/kı çocuklar için örme giyim eşyası & $\% 5.37$ & $\% 2.84$ & $\% 1.79$ & \%1.41 & 1 & 1 & 1 & 1 \\
\hline & & 651 & Tekstil iplikleri & $\% 2.33$ & $\% 1.67$ & $\% 1.16$ & $\% 1.21$ & 1 & 1 & 1 & 1 \\
\hline & & 653 & Sentetik veya suni flamentler ve devamsiz liflerden mensucat & $\% 2.52$ & $\% 1.79$ & $\% 1.35$ & $\% 1.19$ & 1 & 1 & 1 & 1 \\
\hline & & 652 & Pamuklu mensucat & $\% 1.72$ & $\% 1.39$ & $\% 1.10$ & $\% 0.88$ & 1 & 1 & 1 & 1 \\
\hline & & 846 & Givim eşyası iç aksesuar ve givim eşyası parçaları (çorap, mendil, eldiven vb.) & $\% 1.19$ & $\% 1.26$ & $\% 0.88$ & $\% 0.87$ & 1 & 1 & 1 & 1 \\
\hline & & 697 & Adi metalerden ev işlerinde kullanılan eşva ve aksam & $\% 0.40$ & $\% 0.75$ & $\% 0.55$ & $\% 0.56$ & 1 & 1 & 1 & 1 \\
\hline & & 657 & 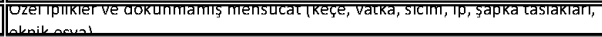 & $\% 0.54$ & $\% 0.54$ & $\% 0.44$ & $\% 0.52$ & 1 & 1 & 1 & 1 \\
\hline & & 662 & Silisli fosil unları ve benzerlerinden eşva, tuğla, kiremit, karolar vb. eşya & $\% 0.66$ & $\% 0.74$ & $\% 0.54$ & $\% 0.52$ & 1 & 1 & 1 & 1 \\
\hline & & 843 & Erkek/erkek çocuklar için örme giyim eşvası & $\% 1.30$ & $\% 0.66$ & $\% 0.51$ & $\% 0.51$ & 1 & 1 & 1 & 1 \\
\hline & & 851 & Ayakkabılar ve aksamı & $\% 0.53$ & $\% 0.39$ & $\% 0.30$ & $\% 0.49$ & 0 & 0 & 0 & 0 \\
\hline & & 665 & Züccaciye, cam eşya & $\% 0.67$ & $\% 0.67$ & $\% 0.40$ & $\% 0.37$ & 1 & 1 & 1 & 1 \\
\hline & & 641 & Kağılt ve karton & $\% 0.37$ & $\% 0.31$ & $\% 0.20$ & $\% 0.35$ & 0 & 0 & 0 & 0 \\
\hline & & 848 & Tekstil dışında kalan giyim eşvası, şapka vs. & $\% 2.18$ & $\% 0.89$ & $\% 0.40$ & $\% 0.30$ & 1 & 1 & 1 & 1 \\
\hline & & 664 & Cam & $\% 0.35$ & $\% 0.37$ & $\% 0.34$ & $\% 0.27$ & 1 & 1 & 1 & 1 \\
\hline & & 656 & Kordelalar, etiketler, armalar, tüller vb. & $\% 0.27$ & $\% 0.64$ & $\% 0.37$ & $\% 0.25$ & 1 & 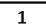 & 1 & $\overline{11}$ \\
\hline & & 899 & Başka yerde belirtilmemiş çeşitli işlenmiş eşyalar & $\% 0.12$ & $\% 0.15$ & $\% 0.14$ & $\% 0.16$ & 0 & 0 & 0 & 0 \\
\hline & & 263 & Pamuk, linter pamuğu ve pamuk döküntüleri & $\% 0.22$ & $\% 0.34$ & $\% 0.17$ & $\% 0.14$ & 0 & 1 & 1 & 1 \\
\hline & & 611 & |ş̧lenmiş deri ve köseleler & $\% 0.13$ & $\% 0.10$ & $\% 0.10$ & $\% 0.13$ & 0 & 0 & 0 & 0 \\
\hline
\end{tabular}




\begin{tabular}{|c|c|c|c|c|c|c|c|c|c|c|c|}
\hline \multirow[b]{2}{*}{ Geleneksellik } & \multirow[b]{2}{*}{$\begin{array}{c}\text { Teknoloji } \\
\text { Grubu }\end{array}$} & \multirow[b]{2}{*}{$\begin{array}{c}\text { Sektör } \\
\text { Kodu }\end{array}$} & \multirow[b]{2}{*}{ Sektör Adı } & \multicolumn{4}{|c|}{ 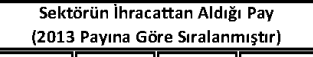 } & \multicolumn{4}{|c|}{$\begin{array}{l}\text { Karşslaştrmalh Üstünlük Var mı? } \\
\text { (Varsa 1, Yoksa o) }\end{array}$} \\
\hline & & & & 1995 & 2003 & 2007 & 2013 & 1995 & 2003 & 2007 & 2013 \\
\hline & & 831 & Sandıklar, bavullar, çantalar ve kılıflar & $\% 0.16$ & $\% 0.10$ & $\% 0.12$ & $\% 0.13$ & 0 & 0 & 0 & 0 \\
\hline & & 695 & El aletleri ve makineler için aletter & \%0.08 & $\% 0.07$ & $\% 0.09$ & \%0.12 & 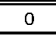 & 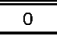 & 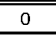 & 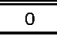 \\
\hline & & 654 & Dokum & $\% 0.31$ & $\% 0.25$ & $\% 0.18$ & $\% 0.11$ & 1 & 1 & 1 & 1 \\
\hline & & 892 & Basılmıs yayınlar & $\% 0.07$ & $\% 0.09$ & $\% 0.10$ & $\% 0.10$ & 0 & 0 & 0 & 0 \\
\hline & & 666 & Çanak-çömlek & $\% 0.06$ & $\% 0.08$ & $\% 0.07$ & $\% 0.06$ & 0 & 1 & 1 & 1 \\
\hline & & 266 & Sentetik flament demetleri ver sentetik devamlı lifler & $\% 0.46$ & $\% 0.05$ & $\% 0.07$ & $\% 0.05$ & 1 & 0 & 1 & 1 \\
\hline & & 268 & Yün/vapağı ve diĕ̌er hayvan kll & $\% 0.03$ & $\% 0.04$ & $\% 0.03$ & $\% 0.03$ & 0 & 0 & 0 & 0 \\
\hline & & 898 & Müzik aletleri ve bunların aksam ve parçaları & $\% 0.39$ & $\% 0.06$ & $\% 0.03$ & $\% 0.03$ & 0 & 0 & 0 & 0 \\
\hline & & 895 & Büro eģyası, krrtasiye malzemeleri & $\% 0.03$ & $\% 0.04$ & $\% 0.02$ & $\% 0.02$ & 0 & $\overline{0}$ & 0 & $\overline{0}$ \\
\hline & & 896 & Sanat ve kolleksiyon eşyası, antika esya & $\% 0.00$ & $\% 0.00$ & $\% 0.00$ & $\% 0.01$ & 0 & 0 & 0 & 0 \\
\hline & & 269 & Kullanılmıs givim eşvası ve parçaları & $\% 0.06$ & $\% 0.03$ & $\% 0.01$ & $\% 0.01$ & 1 & 1 & 0 & 0 \\
\hline & & 612 & 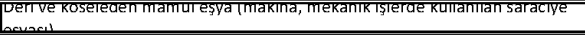 & $\% 0.02$ & $\% 0.02$ & $\% 0.02$ & $\% 0.01$ & $\overline{0}$ & 0 & 0 & $\overline{0}$ \\
\hline & & 633 & Mantardan eşva & $\% 0.00$ & $\% 0.00$ & $\% 0.00$ & $\% 0.00$ & 0 & 0 & 0 & 0 \\
\hline & & 261 & ipek & $\% 0.00$ & $\% 0.00$ & $\% 0.00$ & $\% 0.00$ & 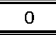 & $\overline{0}$ & 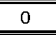 & $\overline{0}$ \\
\hline & & 265 & Dokumaya elverişli diğer bitkisel lifler & $\% 0.00$ & $\% 0.00$ & $\% 0.00$ & $\% 0.00$ & 0 & 0 & 0 & 0 \\
\hline \multirow{16}{*}{ 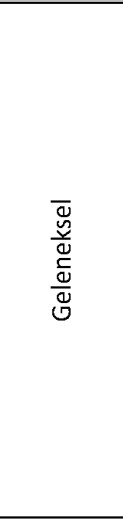 } & \multirow{16}{*}{ 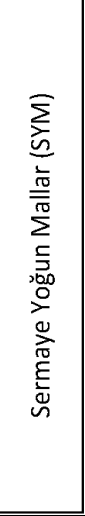 } & 625 & Kauçuktan iç ve dış lastikler (veni/eski) & $\% 1.05$ & $\% 1.00$ & $\% 0.85$ & $\% 0.81$ & 1 & 1 & 1 & 1 \\
\hline & & 783 & Başka yerde belirtilmeyen motorlu karayolu taşıtları & $\% 0.66$ & $\% 1.12$ & $\% 1.55$ & $\% 0.81$ & 1 & 1 & 1 & 1 \\
\hline & & 673 & Demir veya alaşımsız çelikten kaplanmamıs vassı hadde mamulleri & $\% 0.42$ & $\% 0.60$ & $\% 0.56$ & $\% 0.73$ & 0 & 1 & 0 & 1 \\
\hline & & 672 & Demir veya çelikten külç ve diš̆er ilk şekillerde yarı mamuller & $\% 1.99$ & $\% 1.64$ & $\% 0.84$ & $\% 0.63$ & 1 & 1 & 1 & 1 \\
\hline & & 554 & Sabunlar, temizleme, cilalama ürünleri & $\% 0.90$ & $\% 0.67$ & $\% 0.46$ & $\% 0.60$ & 1 & 1 & 1 & 1 \\
\hline & & 682 & Bakır ve bakırdan çubuk, profil, tel, saç, serit, boru vb. & $\% 0.69$ & $\% 0.30$ & $\% 0.54$ & $\% 0.58$ & 1 & 0 & 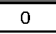 & $\overline{0}$ \\
\hline & & 122 & islenmiş tütün & $\% 0.63$ & $\% 0.19$ & $\% 0.19$ & $\% 0.32$ & 1 & 0 & 1 & 1 \\
\hline & & 121 & Yaprak tütün ve tütün döküntüleri & $\% 1.13$ & $\% 0.71$ & $\% 0.43$ & $\% 0.30$ & 1 & 1 & 1 & 1 \\
\hline & & 786 & Römorklar ve yarı römorklar & $\% 0.42$ & $\% 0.13$ & $\% 0.26$ & $\% 0.22$ & 1 & 0 & 1 & 1 \\
\hline & & 111 & Alkolsüz içeçekler & $\% 0.18$ & $\% 0.07$ & $\% 0.08$ & $\% 0.12$ & 1 & 0 & 0 & 0 \\
\hline & & 671 & Dökme ve aynali demir, ferro alyajlar & $\% 0.34$ & $\% 0.07$ & $\% 0.08$ & $\% 0.12$ & 1 & 0 & 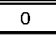 & 0 \\
\hline & & 112 & Alkollü içecekler & $\% 0.21$ & $\% 0.08$ & $\% 0.07$ & $\% 0.08$ & 0 & 0 & 0 & 0 \\
\hline & & 785 & Motosikletler, bisikletler, sakatlar için koltuklar vb. aksam parçaları & $\% 0.08$ & $\% 0.10$ & $\% 0.06$ & $\% 0.06$ & 0 & 0 & 0 & 0 \\
\hline & & 551 & Uçucu yağlar rezinoitler & $\% 0.04$ & $\% 0.05$ & $\% 0.03$ & $\% 0.05$ & 0 & 0 & 0 & 0 \\
\hline & & 686 & Cinko ve çinkodan çubuk, profil, tel, saç, serit, boru vb. & $\% 0.00$ & $\% 0.00$ & $\% 0.00$ & $\% 0.00$ & 0 & 0 & 0 & 0 \\
\hline & & 685 & Kurşun & $\% 0.00$ & $\% 0.00$ & $\% 0.00$ & $\% 0.00$ & 0 & 0 & 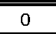 & $\overline{0}$ \\
\hline \multirow{13}{*}{ 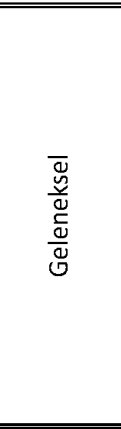 } & \multirow{13}{*}{ 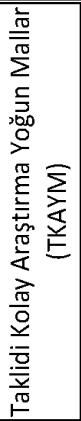 } & 761 & Televizyon aliciları (kombine olsun olmasın) & \%0.93 & $\% 3.91$ & \%2.35 & \%1.17 & 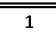 & 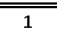 & 1 & 1 \\
\hline & & 764 & Telli telefon ve telgraf cihazlar, telsiz telefon telgraf vihazları vb. aksamı & $\% 0.19$ & $\% 0.22$ & $\% 0.16$ & $\% 0.21$ & 0 & 0 & 0 & 0 \\
\hline & & 541 & Eczacillk ve eczacillk ürünleri & $\% 0.08$ & $\% 0.11$ & $\% 0.08$ & $\% 0.08$ & 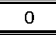 & 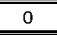 & 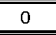 & $\overline{0}$ \\
\hline & & 523 & Diëer inorganik kimyasal maddeler & $\% 0.48$ & $\% 0.07$ & $\% 0.05$ & $\% 0.08$ & 1 & 0 & 0 & 0 \\
\hline & & 752 & Otomatik bilgi işlem makinalari vb. ait birimler & $\% 0.02$ & $\% 0.06$ & $\% 0.09$ & $\% 0.07$ & 0 & 0 & 0 & 0 \\
\hline & & 591 & Haşarat öldürücüler ve zararlı bitkileri yok ediciler & $\% 0.09$ & $\% 0.05$ & $\% 0.05$ & $\% 0.06$ & 0 & 0 & 0 & $\overline{0}$ \\
\hline & & 514 & Azot fonksiyonlu bilegikler & $\% 0.12$ & $\% 0.05$ & $\% 0.04$ & $\% 0.04$ & 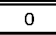 & 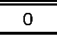 & 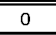 & 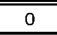 \\
\hline & & 759 & Büro ver bilgi işlem makinalarııın aksam ve parçaları & $\% 0.01$ & $\% 0.02$ & $\% 0.03$ & $\% 0.03$ & 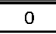 & $\overline{0}$ & $\overline{0}$ & $\overline{0}$ \\
\hline & & $\overline{512}$ & Alkoller, fenoller, fenol-alkoller vb. türevleri & $\% 0.12$ & $\% 0.06$ & $\% 0.03$ & $\% 0.03$ & 0 & 0 & 0 & $\overline{0}$ \\
\hline & & 763 & Plak döndürücüler, pikaplar, kaset çalarlar, video kayıt ve gösterme cihazları & $\% 0.00$ & $\% 0.01$ & $\% 0.05$ & $\% 0.02$ & 0 & 0 & 0 & 0 \\
\hline & & 515 & Organo-inorganik, heterosiklik bilesikler, nükleik asitler & $\% 0.06$ & $\% 0.02$ & $\% 0.01$ & $\% 0.01$ & 0 & 0 & 0 & 0 \\
\hline & & 524 & Oksi ve peroksi metalik asitlerin tuzlar, kivmetli metallerin bilesikleri & $\% 0.05$ & $\% 0.01$ & $\% 0.02$ & $\% 0.01$ & 0 & 0 & 0 & 0 \\
\hline & & 762 & Telsiz telefon, telsiz telgraf ve radyo yayinları için alıı cihazlar & $\% 0.00$ & $\% 0.00$ & $\% 0.00$ & $\% 0.00$ & 0 & 0 & 0 & 0 \\
\hline \multirow{10}{*}{ 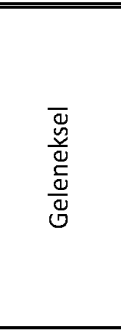 } & & 792 & Hava taşıtları, uzay araçları vb. aksam, parçaları & $\% 0.02$ & $\% 0.95$ & $\% 0.50$ & $\% 0.47$ & $\overline{0}$ & $\overline{0}$ & $\overline{0}$ & $\overline{0}$ \\
\hline & 250 & 714 & Turbojetler, tepkili motorlar, diğer gaz türbinleri vb. aksamı & $\% 0.12$ & $\% 0.21$ & $\% 0.34$ & $\% 0.18$ & 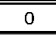 & $\overline{0}$ & 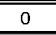 & 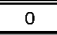 \\
\hline & & 726 & Matbaacilikta kullanilan makinalar & $\% 0.01$ & $\% 0.02$ & $\% 0.03$ & $\% 0.03$ & 0 & 0 & 0 & $\overline{0}$ \\
\hline & & 776 & Katod ışını tüpler, varı iletken tertibat; elektrik devreleri & $\% 0.01$ & $\% 0.03$ & $\% 0.04$ & $\% 0.03$ & 0 & 0 & 0 & 0 \\
\hline & $\min _{\pi}^{n}$ & 882 & Fotoğrafçıllkta kullanılan filmler, kimyasal müstahzarlar ve kağıt, karton vs. & $\% 0.01$ & $\% 0.01$ & $\% 0.01$ & $\% 0.02$ & 0 & 0 & 0 & 0 \\
\hline & $\frac{2}{2}$ & 573 & Vinil klorür veya halojenli diğerer olefin polimerleri (ilk şekilde) & $\% 0.07$ & $\% 0.01$ & $\% 0.01$ & $\% 0.02$ & 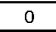 & 0 & $\overline{0}$ & 0 \\
\hline & $\vdots \frac{0}{\overline{0}}$ & 884 & Optik cihazlar ile aksam ve parçaları & \%0.01 & $\% 0.01$ & $\% 0.01$ & $\% 0.01$ & 0 & 0 & 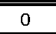 & $\overline{0}$ \\
\hline & 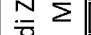 & 712 & Buhar turbinleri ile aksam ve parçaları & $\% 0.00$ & $\% 0.00$ & $\% 0.00$ & $\% 0.00$ & 0 & 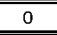 & 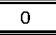 & 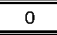 \\
\hline & $\frac{-2}{\bar{x}}$ & 881 & Sinema ve fotoğrafçılıkla ilgili aletler & $\% 0.00$ & $\% 0.00$ & $\% 0.00$ & $\% 0.00$ & 0 & 0 & 0 & 0 \\
\hline & & 883 & Sinemacillkta kullanılan filmler & $\% 0.00$ & $\% 0.00$ & $\% 0.00$ & $\% 0.00$ & 0 & 0 & 0 & 0 \\
\hline & & 334 & Rafine edilmiş petrol ürünleri & $\% 1.21$ & $\% 1.72$ & $\% 4.52$ & $\% 4.06$ & 0 & 0 & 1 & 0 \\
\hline & & 273 & Taș, mermer, alçı taşı, kireç tașı, kum & $\% 0.08$ & $\% 0.31$ & $\% 0.43$ & $\% 0.87$ & 1 & 1 & 1 & 1 \\
\hline & & 46 & Buğday ve mahlut unu, bulgur, irmik ve pellet & $\% 0.67$ & $\% 0.25$ & $\% 0.42$ & $\% 0.66$ & 1 & 1 & 1 & 1 \\
\hline & & 287 & Diěer metal cevherleri & $\% 0.50$ & $\% 0.12$ & $\% 0.48$ & $\% 0.64$ & 1 & 1 & 1 & 1 \\
\hline & & 98 & Baska yerde sinfflandirlimamış gida mustahzarları & $\% 0.30$ & $\% 0.34$ & $\% 0.42$ & $\% 0.51$ & 0 & 1 & 1 & 1 \\
\hline & & 12 & Hayvanların (sığı̆r hariç̧) eti-taze/soğutulmuş/dondurulmuş & $\% 0.10$ & $\% 0.04$ & $\% 0.04$ & $\% 0.42$ & 0 & $\overline{0}$ & 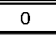 & 0 \\
\hline & & 283 & Bakır cevherleri, matları ve çöktürülmüş bakır & $\% 0.20$ & $\% 0.10$ & $\% 0.32$ & $\% 0.35$ & 1 & 0 & 1 & 1 \\
\hline & & 34 & Ballklar-canl, taze/soğutulmuş/dondurulmus & $\% 0.10$ & $\% 0.19$ & $\% 0.20$ & $\% 0.30$ & 0 & 0 & 0 & 0 \\
\hline
\end{tabular}




\begin{tabular}{|c|c|c|c|c|c|c|c|c|c|c|c|}
\hline \multirow[b]{2}{*}{ Geleneksellik } & \multirow[b]{2}{*}{$\begin{array}{c}\text { Teknoloji } \\
\text { Grubu }\end{array}$} & \multirow[b]{2}{*}{$\begin{array}{l}\text { Sektör } \\
\text { Kodu }\end{array}$} & \multirow[b]{2}{*}{ Sektör Adı } & \multicolumn{4}{|c|}{ 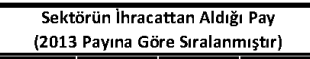 } & \multicolumn{4}{|c|}{$\begin{array}{c}\text { Karşllaştrtrmall Üstünlü̈ Var mı ? } \\
\text { (Varsa 1, Yoksa 0) }\end{array}$} \\
\hline & & & & 1995 & 2003 & 2007 & 2013 & 1995 & 2003 & 2007 & 2013 \\
\hline \multirow{27}{*}{ 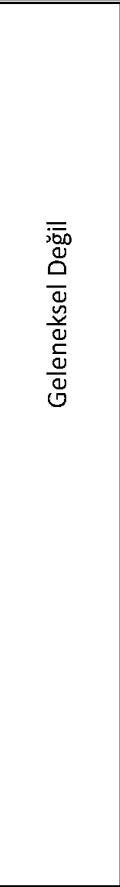 } & \multirow{27}{*}{ 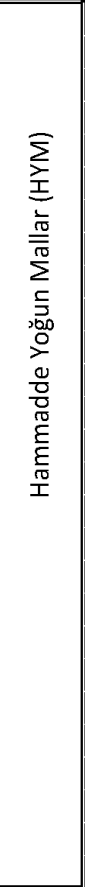 } & 25 & Yumurta ve vumurta albüminleri & $\% 0.04$ & $\% 0.02$ & $\% 0.06$ & $\% 0.28$ & 1 & 0 & 1 & 1 \\
\hline & & 344 & Sivvlaştriılıış etilen, propilen, butilen, petrol gazı & $\% 0.05$ & $\% 0.29$ & $\% 0.10$ & $\% 0.18$ & 0 & 1 & 0 & 1 \\
\hline & & 289 & Kivmetli metal cevherleri ve hurdaları & $\% 0.00$ & $\% 0.01$ & $\% 0.05$ & $\% 0.15$ & 0 & 0 & 0 & 1 \\
\hline & & 335 & Petrol ürünleri artıkları & $\% 0.07$ & $\% 0.03$ & $\% 0.08$ & $\% 0.14$ & 0 & 0 & 0 & 0 \\
\hline & & 81 & Havvan gidası olarak kullanılan maddeler & $\% 0.05$ & $\% 0.03$ & $\% 0.01$ & $\% 0.14$ & 0 & 0 & 0 & 0 \\
\hline & & 24 & Peynirve lor & $\% 0.05$ & $\% 0.05$ & $\% 0.05$ & \%0.11 & 0 & 0 & 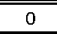 & 0 \\
\hline & & 282 & Demir-çelik döküntü ve hurdaları, bunların külçeleri & $\% 0.06$ & $\% 0.08$ & $\% 0.17$ & $\% 0.09$ & 0 & 0 & 0 & 0 \\
\hline & & 222 & Yağl| tohumlar ve meyvaları (kırılmıı olsun olmasın) & $\% 0.04$ & $\% 0.03$ & $\% 0.04$ & $\% 0.09$ & 0 & 0 & 0 & 0 \\
\hline & & 22 & Süt ve krema & $\% 0.03$ & $\% 0.03$ & $\% 0.05$ & $\% 0.09$ & 0 & 0 & 0 & 0 \\
\hline & & 562 & Mineral kimyasal gübreler (272.grubun dı̧̣ındakiler) & $\% 0.09$ & $\% 0.04$ & $\% 0.08$ & $\% 0.07$ & 0 & 0 & 0 & 0 \\
\hline & & 44 & Misir & $\% 0.02$ & $\% 0.03$ & $\% 0.01$ & $\% 0.06$ & 0 & 0 & 0 & 0 \\
\hline & & 281 & Demir cevherleri & $\% 0.00$ & $\% 0.00$ & $\% 0.00$ & $\% 0.06$ & 0 & 0 & 0 & 0 \\
\hline & & 17 & Baska yerde sinflandırılmamıs hazırlanmış et ve et ürünleri & $\% 0.01$ & $\% 0.00$ & $\% 0.01$ & $\% 0.04$ & 0 & 0 & 0 & 0 \\
\hline & & 47 & Diěer hububat un, bulgur, irmik ve pellet. & $\% 0.00$ & $\% 0.00$ & $\% 0.01$ & $\% 0.03$ & 0 & 0 & 1 & 1 \\
\hline & & 35 & Balkklar (kuru/tuzlu/salamura/tuttsülü) insan yemesi için balk unu/ezmesi/pelleti & $\% 0.00$ & $\% 0.01$ & $\% 0.02$ & $\% 0.03$ & 0 & 0 & 0 & 0 \\
\hline & & 71 & Kahve & $\% 0.00$ & $\% 0.00$ & $\% 0.01$ & $\% 0.02$ & 0 & 0 & 0 & 0 \\
\hline & & 251 & Odun veya diĕer liffl selilozik maddeler; hamurları, döküntü ve kırpıntıları & $\% 0.01$ & $\% 0.00$ & $\% 0.00$ & $\% 0.02$ & 0 & 0 & 0 & 0 \\
\hline & & 272 & Hayvansal ve bitkisel gübreler, tabi kalsiyum fosfat ve diğer tabi potasyum tuzlar & $\% 0.00$ & $\% 0.00$ & $\% 0.00$ & $\% 0.01$ & 0 & 0 & 0 & 0 \\
\hline & & 42 & Pirinç & $\% 0.00$ & $\% 0.00$ & $\% 0.00$ & $\% 0.01$ & 0 & 0 & 0 & 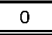 \\
\hline & & 274 & Kükürt ve demir piritleri & $\% 0.00$ & $\% 0.00$ & $\% 0.00$ & $\% 0.00$ & 0 & 0 & 0 & 0 \\
\hline & & 231 & Tabii kauçuk, balata, güte-parka, guayül, çıkıl & $\% 0.00$ & $\% 0.00$ & $\% 0.00$ & $\% 0.00$ & 0 & 0 & 0 & 0 \\
\hline & & 284 & Nikel cevherleri ve nikel oksit & $\% 0.00$ & $\% 0.00$ & $\% 0.01$ & $\% 0.00$ & 0 & 0 & 0 & 0 \\
\hline & & 322 & Linyit ve turb, linyit, taş kömürü ve turbdan elde edilen kat yakitlar & $\% 0.00$ & $\% 0.00$ & $\% 0.00$ & $\% 0.00$ & 0 & 0 & 0 & 0 \\
\hline & & 16 & Et ve yenilen sakatat-tuzlu/salamura/kurutulmuş-sakatat un ve ezmeleri & $\% 0.00$ & $\% 0.00$ & $\% 0.00$ & 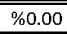 & 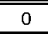 & 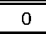 & 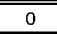 & 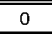 \\
\hline & & 245 & Yakmaya mahsus ağ̌aclar ve odun komürü & $\% 0.00$ & $\% 0.00$ & $\% 0.00$ & $\% 0.00$ & 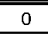 & 0 & 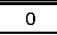 & 0 \\
\hline & & 246 & Yakmaya mahsus yonga halinde ağaçlar ve testere talaṣı & $\% 0.00$ & $\% 0.00$ & $\% 0.00$ & $\% 0.00$ & 0 & 0 & 0 & 0 \\
\hline & & 343 & Doğal gaz & $\% 0.00$ & $\% 0.00$ & $\% 0.00$ & $\% 0.00$ & 0 & 0 & 0 & 0 \\
\hline \multirow{24}{*}{ 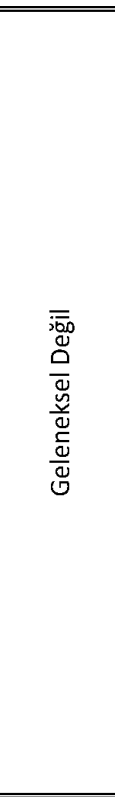 } & \multirow{24}{*}{ 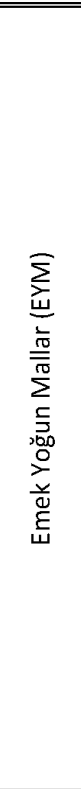 } & 897 & |Kkymetti, yar kymetli, kaplama metallerlerden kuyumcu ver mücevherci esyası & $\% 0.30$ & \%1.56 & \%1.49 & \%2.35 & 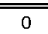 & 1 & 1 & 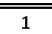 \\
\hline & & 659 & Halllar ve diğer ver kaplamaları & $\% 1.16$ & $\% 0.82$ & $\% 0.94$ & $\% 1.50$ & 1 & 1 & 1 & 1 \\
\hline & & 821 & Mobilya, aksam ve parçaları & $\% 0.34$ & $\% 0.97$ & $\% 1.02$ & \%1.49 & 0 & 0 & 1 & 1 \\
\hline & & 699 & Diěer adi metallerden eşva (kilit, zincir, yay, fermuar, dikiș, nakiş aletleri vb.) & $\% 0.42$ & $\% 0.76$ & $\% 1.02$ & $\% 1.39$ & 0 & 0 & 1 & 1 \\
\hline & & 893 & Plastikten mamul esya & $\% 0.52$ & $\% 0.81$ & $\% 0.91$ & \%1.29 & 0 & 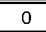 & 1 & 1 \\
\hline & & 661 & Kireç, çimento, tabii taşlar, asfalt ile bunlardan eșya & $\% 0.98$ & $\% 1.45$ & $\% 1.43$ & $\% 1.29$ & 1 & 1 & 1 & 1 \\
\hline & & 655 & Örme mensucat & $\% 0.39$ & $\% 0.74$ & $\% 0.96$ & $\% 1.15$ & 1 & 1 & 1 & 1 \\
\hline & & 691 & Demir, çelik veva aluminyumdan inşaat ve iņaat aksamı & $\% 0.32$ & $\% 0.53$ & $\% 0.95$ & \%1.13 & 1 & 1 & 1 & 1 \\
\hline & & 642 & Kăğt, kağ̈t hamuru, karton ver selülozik liflerden mamul esva & $\% 0.22$ & $\% 0.50$ & $\% 0.59$ & $\% 0.96$ & 0 & 1 & 1 & 1 \\
\hline & & 812 & 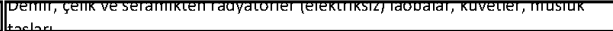 & $\% 0.36$ & $\% 0.75$ & $\% 0.78$ & $\% 0.71$ & 1 & 1 & 1 & 1 \\
\hline & & 693 & Alum inyum, bakir veya demir çelikten teller, halatlar, kablolar, mensucat & $\% 0.20$ & $\% 0.36$ & $\% 0.39$ & $\% 0.50$ & 1 & 1 & 1 & 1 \\
\hline & & 692 & Demir çelik veya aluminyumdan depo, sarnıç, vb. kaplar & $\% 0.09$ & $\% 0.17$ & $\% 0.26$ & $\% 0.32$ & 0 & 1 & 1 & 1 \\
\hline & & 6334 & Kaplamalikk ağaçlar, levhalar, kontaplak, sırrk, kazık vs, ile ağaç vünü & $\% 0.08$ & $\% 0.19$ & $\% 0.30$ & $\% 0.29$ & 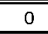 & 0 & 1 & 1 \\
\hline & & 694 & Bakrr, Aluminyum, demir veva çelikten çivi, vida, pim, rondela vb. esva & $\% 0.11$ & $\% 0.12$ & $\% 0.17$ & $\% 0.21$ & 0 & 0 & 0 & 0 \\
\hline & & 811 & Prefabrik yapılar & $\% 0.07$ & $\% 0.22$ & $\% 0.20$ & $\% 0.20$ & 1 & 1 & 1 & 1 \\
\hline & & 813 & |sisklı isim tabelaları ve aksamı, portatif elektrik lambaları & $\% 0.13$ & $\% 0.16$ & $\% 0.18$ & $\% 0.20$ & 0 & 0 & 1 & 0 \\
\hline & & 891 & Ateşli harp silahları ve malzemeleri & $\% 0.06$ & $\% 0.16$ & $\% 0.13$ & $\% 0.19$ & 0 & 1 & 1 & 1 \\
\hline & & 663 & Mineral maddelerden mamul diğer eşva ve cihazlar & $\% 0.10$ & $\% 0.13$ & $\% 0.13$ & $\% 0.18$ & 0 & 0 & 0 & 0 \\
\hline & & 635 & Ağăçtan muhafazalar, kutu, kafes sandik, vs. ile inşaat ve marangozluk mamülleri & $\% 0.11$ & $\% 0.08$ & $\% 0.10$ & $\% 0.18$ & 0 & 0 & 0 & 1 \\
\hline & & 894 & Çocuk arabaları, oyuncaklar, spor malzemeleri & $\% 0.03$ & $\% 0.05$ & $\% 0.05$ & $\% 0.08$ & 0 & 0 & 0 & 0 \\
\hline & & 613 & Dabaklanmış, aprelenmiş, bütün halinde kürkler & $\% 0.03$ & $\% 0.03$ & $\% 0.04$ & $\% 0.07$ & 1 & 1 & 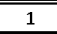 & 1 \\
\hline & & 696 & Bıçakçı eşyası ve sofra takımları, bunların aksam ve parçaları & $\% 0.03$ & $\% 0.02$ & $\% 0.03$ & $\% 0.03$ & 0 & 0 & 0 & 0 \\
\hline & & 267 & Diğer suni lifler ve arttkları & $\% 0.01$ & $\% 0.00$ & $\% 0.00$ & $\% 0.01$ & 0 & 0 & 0 & 0 \\
\hline & & 667 & inciler ve kvymetli metal tașlar & $\% 0.00$ & $\% 0.00$ & $\% 0.00$ & $\% 0.00$ & 0 & 0 & 0 & 0 \\
\hline \multirow{12}{*}{ 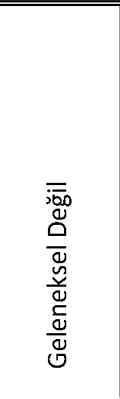 } & & 781 & Motorlu yolcu tastitlar (binek otomobilleri vb.) & \%1.16 & $\% 4.72$ & $\% 6.51$ & $\% 4.68$ & 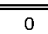 & 0 & 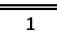 & 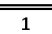 \\
\hline & & 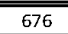 & Demir veya çelikten (alaşımlı, alaşımsız) filmaşin, çubuk ve profiller & $\% 5.07$ & 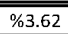 & $\% 5.85$ & 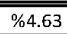 & 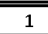 & $\overline{11}$ & $\overline{1}$ & $\overline{11}$ \\
\hline & $\Xi$ & 784 & Motorlu taşıtların aksam ve parçaları ile şase ve karoserleri & $\% 0.84$ & $\% 2.05$ & $\% 2.46$ & 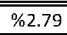 & 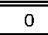 & 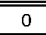 & 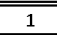 & 1 \\
\hline & స & 782 & Esyya taşımaya mahsus motorlu taşıtlar & $\% 0.20$ & $\% 2.52$ & $\% 4.10$ & 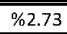 & 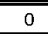 & $\overline{1}$ & $\overline{1}$ & 1 \\
\hline & & 879 & Demir veva çelikten ince, kalin borular ve içi bos profiller, boru bağlantı parçaları & $\% 1.14$ & $\% 0.87$ & 81.32 & 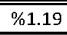 & 1 & 1 & 1 & 1 \\
\hline & & 684 & Aluminyum ve aluminyumdan çubuk, profil, tel, saç, serit, boru vb. & $\% 0.55$ & $\% 0.67$ & $\% 1.12$ & $\% 1.05$ & 0 & 0 & 1 & 1 \\
\hline & $\mathrm{J}$ & 629 & Kauçuktan diĕer eşva (hijenik, eczaclilk ürünleri, taşlylıı kolonlar) & $\% 0.10$ & $\% 0.28$ & $\% 0.37$ & $\% 0.47$ & 0 & 1 & 1 & 1 \\
\hline & & 553 & Parfüm ve kozmetik veva tuvalet mustahzarları & $\% 0.08$ & $\% 0.28$ & $\% 0.31$ & $\% 0.43$ & 0 & 0 & 0 & 0 \\
\hline & $\pi$ & 533 & Pigmentler, vernikler, boyalar & $\% 0.18$ & $\% 0.23$ & $\% 0.27$ & $\% 0.43$ & 0 & 0 & 0 & 1 \\
\hline & 5 & 674 & Demir veya alaşıs SIz çelikten kaplanmış yassı hadde mamulleri & $\% 0.09$ & $\% 0.22$ & $\% 0.27$ & $\% 0.38$ & 0 & 0 & 0 & 1 \\
\hline & 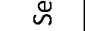 & 621 & kauçuk ve kauçuktan eşya & $\% 0.13$ & $\% 0.18$ & $\% 0.28$ & $\% 0.37$ & 1 & 1 & 1 & 1 \\
\hline & & 678 & Demir veya çelikten teller & $\% 0.08$ & $\% 0.06$ & $\% 0.09$ & $\% 0.13$ & 0 & 0 & 1 & 1 \\
\hline
\end{tabular}




\begin{tabular}{|c|c|c|c|c|c|c|c|c|c|c|c|}
\hline \multirow[b]{2}{*}{ Geleneksellik } & \multirow[b]{2}{*}{\begin{tabular}{|c} 
Teknoloj \\
Grubu
\end{tabular}} & \multirow[b]{2}{*}{$\begin{array}{l}\text { Sektör } \\
\text { Kodu }\end{array}$} & \multirow[b]{2}{*}{ Sektör Adı } & \multicolumn{4}{|c|}{$\begin{array}{l}\text { Sektörün İhracattan Aldığı Pay } \\
\text { (2013 Payına Göre Sıralanmıştır) }\end{array}$} & \multicolumn{4}{|c|}{$\begin{array}{c}\text { Karşlaştırmalı Üstünlük Var mı ? } \\
\text { (Varsa 1, Yoksa 0) }\end{array}$} \\
\hline & & & & 1995 & 2003 & 2007 & 2013 & 1995 & 2003 & 2007 & 2013 \\
\hline & & 681 & Gümüs̆, platin ve gümüş veya platin kaplamalı altın ve diĕer metaller & $\% 0.01$ & $\% 0.00$ & $\% 0.02$ & $\% 0.11$ & 0 & 0 & 0 & 0 \\
\hline & & 675 & Paslanmaz veva alașımsı çelikten yassı hadde mamülleri & $\% 0.00$ & $\% 0.08$ & $\% 0.10$ & $\% 0.07$ & 0 & 0 & 0 & 0 \\
\hline & & 532 & Debagatta kulllanılan boyayıcı hülasalar ve sentetik boyama müstahzarlar & $\% 0.05$ & $\% 0.04$ & $\% 0.05$ & $\% 0.06$ & 1 & 1 & 1 & 1 \\
\hline & & 531 & Sentetik organik boyayıcı maddeler & $\% 0.01$ & $\% 0.03$ & $\% 0.03$ & $\% 0.04$ & 0 & 0 & 0 & 0 \\
\hline & & 677 & Demir veya çelikten demirvolu ve tramvay hattı malzemesi & $\% 0.00$ & $\% 0.00$ & $\% 0.00$ & $\% 0.02$ & 0 & 0 & 0 & 0 \\
\hline & & 351 & Elektrik enerjisi & $\% 0.00$ & $\% 0.04$ & $\% 0.16$ & $\% 0.02$ & 0 & 0 & 0 & 0 \\
\hline & & 689 & 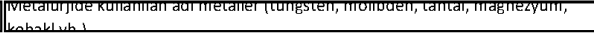 & $\% 0.01$ & $\% 0.00$ & $\% 0.00$ & $\% 0.01$ & 0 & 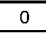 & 0 & 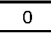 \\
\hline & & 683 & Nikel ve nikelden çubuk, profil, tel, saç, şerit, boru vb. & $\% 0.00$ & $\% 0.00$ & $\% 0.01$ & $\% 0.00$ & 0 & 0 & 0 & 0 \\
\hline & & 687 & Kalay ve kalaydan çubuk, profil, tel, saç, şerit, boru vb. & $\% 0.00$ & $\% 0.00$ & $\% 0.00$ & $\% 0.00$ & 0 & 0 & 0 & 0 \\
\hline \multirow{14}{*}{ 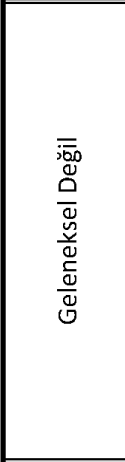 } & \multirow{14}{*}{ 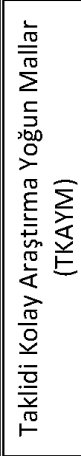 } & 582 & Plastiklerden levhalar, filmler, yapraklar, plakalar & $\% 0.38$ & $\% 0.48$ & $\% 0.60$ & $\% 0.94$ & 0 & 0 & 1 & 1 \\
\hline & & 581 & Plastikten tüpler, borular, hortumlar; conta, dirsek, rakor vb & $\% 0.04$ & $\% 0.25$ & $\% 0.43$ & $\% 0.61$ & 0 & 1 & 1 & 1 \\
\hline & & 542 & |liaçlar & $\% 0.21$ & $\% 0.37$ & $\% 0.31$ & $\% 0.48$ & 0 & 0 & 0 & 0 \\
\hline & & 583 & |Plastikten monofil, çubuk, profiller-enine kesiti 1mmyi geçen & $\% 0.01$ & $\% 0.11$ & $\% 0.27$ & $\% 0.28$ & 0 & 1 & 1 & 1 \\
\hline & & 598 & Diğer kimya sanayi ürünleri & $\% 0.10$ & $\% 0.11$ & $\% 0.17$ & $\% 0.24$ & 0 & 0 & 0 & 0 \\
\hline & & 511 & Hidrokarbonlar ve türevleri & $\% 0.17$ & $\% 0.16$ & $\% 0.16$ & $\% 0.20$ & 0 & 0 & 0 & 0 \\
\hline & & 592 & Nişasta, inülin, buğday gluteni, albuminler, yapışıtıııı ve tutkallar & $\% 0.02$ & $\% 0.04$ & $\% 0.04$ & $\% 0.14$ & 0 & 0 & 0 & 0 \\
\hline & & 522 & 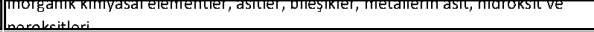 & $\% 0.16$ & $\% 0.06$ & $\% 0.10$ & $\% 0.12$ & 0 & 0 & 0 & 0 \\
\hline & & 513 & Karboksilik asitler ve türevleri & $\% 0.08$ & $\% 0.05$ & $\% 0.05$ & $\% 0.07$ & 0 & 0 & 0 & 0 \\
\hline & & 516 & Diğer organik kimyasal maddeler & $\% 0.02$ & $\% 0.02$ & $\% 0.03$ & $\% 0.04$ & 0 & 0 & 0 & 0 \\
\hline & & 597 & Ateşlemeyi önleyici müstahzarlar, çözücü müstahzarlar, yağlama müstahzarları & $\% 0.01$ & $\% 0.02$ & $\% 0.03$ & $\% 0.03$ & 0 & 0 & 0 & 0 \\
\hline & & 751 & Büro makinaları (yazı, hesap, fotokopi) & $\% 0.02$ & $\% 0.01$ & $\% 0.01$ & $\% 0.02$ & 0 & 0 & 0 & 0 \\
\hline & & 593 & Patlayıcı maddeler, fitiller ve fişekler & $\% 0.00$ & $\% 0.00$ & $\% 0.01$ & $\% 0.01$ & 0 & 0 & 0 & 0 \\
\hline & & 525 & |Radyoaktif elemanlar ve bileşikleri, bunları içeren karışım ve atıklar & $\% 0.00$ & $\% 0.00$ & $\% 0.00$ & $\% 0.01$ & 0 & 0 & 0 & 0 \\
\hline \multirow{42}{*}{ 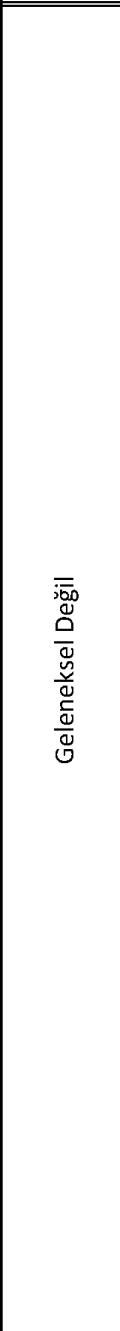 } & \multirow{42}{*}{ 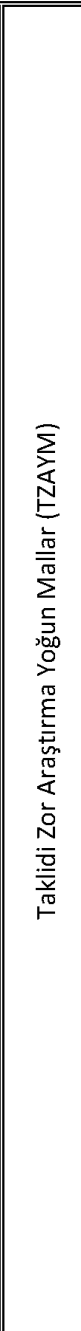 } & 775 & Evlerde kullanılan elektrikli veva elektriksiz diǧer makinalar & $\% 1.08$ & $\% 2.34$ & $\% 2.53$ & $\% 2.63$ & 1 & 1 & 1 & 1 \\
\hline & & 773 & Elektrik dağıııım donanımı (teller, kablolar, izalötörler, bağlantı parçaları) & $\% 1.54$ & $\% 1.11$ & $\% 1.64$ & $\% 1.74$ & 1 & 1 & 1 & 1 \\
\hline & & 713 & Motorlar ve aksamı & $\% 0.52$ & $\% 1.18$ & $\% 1.36$ & $\% 1.27$ & 0 & 1 & 1 & 1 \\
\hline & & 772 & Elektrik devreleri, rezistanslar vb. aksam ve parçaları & $\% 0.27$ & $\% 0.48$ & $\% 0.85$ & $\% 1.04$ & 0 & 0 & 0 & 0 \\
\hline & & 793 & Gemiler ve suda yüzen taştlar & $\% 0.31$ & $\% 0.95$ & $\% 1.73$ & $\% 0.77$ & 0 & 1 & 1 & 0 \\
\hline & & 741 & |sııtııı ve soğutucu ekipmanları, bunların aksam ve parçaları & $\% 0.36$ & $\% 0.57$ & $\% 0.69$ & $\% 0.74$ & 0 & 0 & 0 & 1 \\
\hline & & 728 & Diğer makinalar ve cihazlar ile aksam parçaları & $\% 0.17$ & $\% 0.29$ & $\% 0.56$ & $\% 0.65$ & 0 & 0 & 0 & 0 \\
\hline & & 771 & 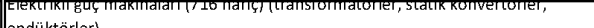 & $\% 0.38$ & $\% 0.34$ & $\% 0.55$ & $\% 0.62$ & 0 & 0 & 1 & 1 \\
\hline & & 743 & Diğer pompalar, fanlar, santrifujler, filtre makine ve cihazları & $\% 0.17$ & $\% 0.25$ & $\% 0.41$ & $\% 0.53$ & 0 & 0 & 0 & 0 \\
\hline & & 778 & Elektrikli makinaların aksam ve parçaları & $\% 0.28$ & $\% 0.33$ & $\% 0.37$ & $\% 0.52$ & 0 & 0 & 0 & 0 \\
\hline & & 723 & Top rağın tesviyesi, cevherleri taşıma, vayılması, kar küreyicileri vb. & $\% 0.16$ & $\% 0.25$ & $\% 0.44$ & $\% 0.43$ & 0 & 0 & 0 & 0 \\
\hline & & 747 & Borular, kanallar, depolar için musluklar, valfler vb. cihazlar & $\% 0.12$ & $\% 0.20$ & $\% 0.24$ & $\% 0.39$ & 0 & 0 & 0 & 0 \\
\hline & & 716 & Elektrik motorları ve jeneratorler ile bunların aksam ve parçaları & $\% 0.13$ & $\% 0.27$ & $\% 0.37$ & $\% 0.33$ & 0 & 0 & 0 & 0 \\
\hline & & 575 & Diğer plastikler (ilk şekillerde) & $\% 0.22$ & $\% 0.17$ & $\% 0.23$ & $\% 0.32$ & 0 & 0 & 0 & 0 \\
\hline & & 744 & Forkliftler, diğer yük arabaları ve kaldııçlar, asansörler & $\% 0.10$ & $\% 0.17$ & $\% 0.21$ & $\% 0.29$ & 0 & 0 & 0 & 0 \\
\hline & & 742 & SIvilar için pompalar, sIVI elevatörleri ile bunların aksam, parçaları & $\% 0.11$ & $\% 0.16$ & $\% 0.26$ & $\% 0.29$ & 0 & 0 & 0 & 0 \\
\hline & & 574 & Poliasetaller ve diğer polieterler ve epoksi reçineler (ilk şekillerde) & $\% 0.15$ & $\% 0.13$ & $\% 0.15$ & $\% 0.24$ & 0 & 0 & 0 & 0 \\
\hline & & 748 & Transmisyon milleri ve kranklar & $\% 0.05$ & $\% 0.15$ & $\% 0.17$ & $\% 0.24$ & 0 & 0 & 0 & 0 \\
\hline & & 722 & Traktörler (744.14 ve 744.15 tekilerin dişındakiler) & $\% 0.00$ & $\% 0.34$ & $\% 0.15$ & $\% 0.23$ & 0 & 1 & 1 & 1 \\
\hline & & 727 & Gıda işleme makinaları & $\% 0.13$ & $\% 0.12$ & $\% 0.16$ & $\% 0.22$ & 1 & 1 & 1 & 1 \\
\hline & & 733 & Vietallemtrao & $\% 0.09$ & $\% 0.19$ & $\% 0.32$ & $\% 0.22$ & 0 & 1 & 1 & 1 \\
\hline & & 749 & Döküm plakaları ve modelleri, kalıplar, contalar & $\% 0.04$ & $\% 0.13$ & $\% 0.13$ & $\% 0.19$ & 0 & 0 & 0 & 1 \\
\hline & & 874 & Ölçü, kontrol, ölçü, ayar alet ver cihazlar, bunların aksam ve parçaları & $\% 0.06$ & $\% 0.12$ & $\% 0.14$ & $\% 0.19$ & 0 & 0 & 0 & 0 \\
\hline & & 724 & Tekstil, çamaşır yıkama ve kurutma, ütüleme makina ve aksam ve parçaları & $\% 0.15$ & $\% 0.20$ & $\% 0.23$ & $\% 0.19$ & 0 & 0 & 1 & 1 \\
\hline & & 745 & Elektrikli olmayan diğer makine ve el aletleri vb. aksam parçaları & $\% 0.05$ & $\% 0.11$ & $\% 0.10$ & $\% 0.18$ & 0 & 0 & 0 & 0 \\
\hline & & 721 & Tarımsal makinalar (traktörler hariç) ve aksam parçaları & $\% 0.04$ & $\% 0.07$ & $\% 0.12$ & $\% 0.18$ & 0 & 0 & 0 & 0 \\
\hline & & 737 & Tav ocakları, döküm potaları, hadde lehim, hadde makinaları & $\% 0.03$ & $\% 0.07$ & $\% 0.15$ & $\% 0.16$ & 0 & 0 & 0 & 1 \\
\hline & & 872 & Tibbi araç ve gereçler & $\% 0.03$ & $\% 0.06$ & $\% 0.08$ & $\% 0.15$ & 0 & 0 & 0 & 0 \\
\hline & & 791 & Demiryolu taşıtları, aksam ve parçaları & $\% 0.02$ & $\% 0.04$ & $\% 0.01$ & $\% 0.12$ & 0 & 0 & 0 & 0 \\
\hline & & 731 & 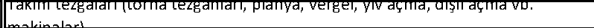 & $\% 0.02$ & $\% 0.04$ & $\% 0.06$ & $\% 0.09$ & 0 & 0 & 0 & 0 \\
\hline & & 746 & Her nevi rulmanlar & $\% 0.05$ & $\% 0.07$ & $\% 0.08$ & $\% 0.08$ & 0 & 0 & 0 & 0 \\
\hline & & 571 & Etilen polimerleri (ilk şekillerde) & $\% 0.07$ & $\% 0.01$ & $\% 0.06$ & $\% 0.07$ & 0 & 0 & 0 & 0 \\
\hline & & 873 & Başka verde sınıflandırılmamış metreler ve sayaçlar & $\% 0.01$ & $\% 0.03$ & $\% 0.03$ & $\% 0.06$ & 0 & 0 & 0 & 0 \\
\hline & & 711 & Buhar kazanları, kızgIn su kazanları ve aksamı & $\% 0.01$ & $\% 0.03$ & $\% 0.04$ & $\% 0.04$ & 0 & 0 & 0 & 0 \\
\hline & & 718 & 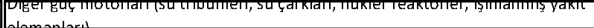 & $\% 0.01$ & $\% 0.02$ & $\% 0.05$ & $\% 0.04$ & 0 & 0 & 0 & 0 \\
\hline & & 735 & Alet tutucular ile 731 ve 733 gruplarındaki makinaların aksam ve parçalar & $\% 0.01$ & $\% 0.02$ & $\% 0.04$ & $\% 0.04$ & 0 & 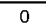 & 0 & 0 \\
\hline & & 572 & Stiren polimerleri (ilk șekillerde) & $\% 0.00$ & $\% 0.00$ & $\% 0.00$ & $\% 0.03$ & 0 & 0 & 0 & 0 \\
\hline & & 725 & Kağıt hamuru, kağıı//karton imaline, ișlenmesine mahsus makina ve cihazlar & $\% 0.01$ & $\% 0.02$ & $\% 0.02$ & $\% 0.02$ & 0 & 0 & 0 & 0 \\
\hline & & 774 & Elektro teşhis cihazlari (X Ișınl, alfa, beta, ve gama ışınlı cihazlar) & $\% 0.00$ & $\% 0.01$ & $\% 0.01$ & $\% 0.02$ & 0 & 0 & 0 & 0 \\
\hline & & 885 & Saatler & $\% 0.01$ & $\% 0.02$ & $\% 0.01$ & $\% 0.02$ & 0 & 0 & 0 & 0 \\
\hline & & 579 & Plastikten döküntü, kalıntı ve hurdalar & $\% 0.00$ & $\% 0.01$ & $\% 0.01$ & $\% 0.02$ & 0 & 0 & 0 & 0 \\
\hline & & 871 & Optik aletler ve aksamı & $\% 0.00$ & $\% 0.01$ & $\% 0.01$ & $\% 0.01$ & 0 & 0 & 0 & 0 \\
\hline
\end{tabular}

